\title{
An Improved Framework for Music Plagiarism Litigation
}

This Comment examines existing and suggested criteria for distinguishing legitimate creative uses of copyrighted musical material from illegitimate uses. It argues that current copyright law fails to take into account both modern theoretical insights into the nature of musical compositions and the social context in which composers create. Abstract tests for "infringement" should be replaced with fact-specific inquiries into market damage and apportionment of each composer's creative contributions to the composite work. Finally, the current bias in favor of injunctive relief should be replaced with a preference for compulsory licensing in order to ensure continued public access to a variety of musical works.

\section{INTRODUCTION}

This Comment is concerned with one aspect of the legal regulation of the creative enterprise: the property rights and economic interests which arise from one composer's musically creative use of another composer's copyrighted musical material. The situations arise from the blending of unoriginal with original musical elements to produce a new work. ${ }^{1}$ This blending causes unique legal problenis for several reasons. First, the new work includes discrete, identifiable elements that do not belong to that work's coniposer, yet these unoriginal parts cannot be removed without destroyimg the whole. Second, the economic value of the borrowed elements, separate from the work as a whole, is virtually indetermniable, so that the proper compensation to the original composer for the use of his material will be difficult to calculate. The effect of the borrowing on the market for the original work is similarly hard to calculate. Finally, the unoriginal material often will be altered in the very process of incorporation into a new context. Thus, this aspect of copyright law revives the difficult and ancient problem of settling rights after a merger of two persons' property, ${ }^{2}$ with a vengeance.

1. Infringement does not require complete or literal copying. See, e.g., Sheldon v. MetroGoldwyn Pictures Corp., 81 F.2d 49, 55-56 (2d Cir.) (play may be plagiarized witlout taking dialogue), cert. denied, 298 U.S. 669 (1936); Nichols v. Universal Pictures Corp., 45 F.2d 119, 121 (2d Cir. 1930) ("It is of course essential to any protection of literary property ... that the right cannot be limited literally to the text, else a plagiarist would escape by immaterial variations. . . [A]s soon as literal appropriation ceases to be the test, the whole matter is necessarily at large, so that . . the decisions cannot help mucl in a new case."), cert. denied, 282 U.S. 902 (1931); Fred Fisher, Inc. v. Dillinglaam, 298 F. 145 (S.D.N.Y. 1924) (use of accompaniment figure but no other part of plaintiff's composition an infringement). See generally 3 M. NIMMER, NIMMER oN COPYRIGHT § 13.03[A][1] \& [2](1987) [hereinafter NimMER].

2. See B. Nicholas, AN Introduction to Roman Law 133-38 (1962). Music copyright 
The elusiveness of the concepts of identity, change, and ownership, which made this problem of merger a constant source of debate among ancient legal scholars, are all present in inusic copyright disputes. But unlike the ancient scholars' arguments over making a statue from another inan's marble, or wine from his grapes, copyright infringement cases are not inerely academic hypotheticals: they are real disputes over economic assets often worth millions of dollars.

Copyright law is designed to resolve such disputes by striking a balance between protecting original creativity (restricting use) and promoting creative enterprise (permitting use). ${ }^{3}$. While the copyright system applies to many sorts of intellectual property, from music to industrial sculpture, the ideal balance may differ according to the expressive medium involved. Thus, to effectuate the balance, different rules and factual inquiries may be necessary depending on the type of creative work at issue.

The basic framework of a plagiarisin ${ }^{4}$ suit requires proof of three elements: First and (usually) easiest, the plaintiff must show that the inaterial which he clains was taken is protected by a valid copyright. ${ }^{5}$ Second, he inust prove that the defendant "copied" this material. ${ }^{6}$ Finally, he inust show that this copying went so far as to be an infringement-the question of "illicit copying."7 If the plaintiff proves these ele-

cases most closely resemble the Roman specificatio-the union of two things so that the identity of the resulting thing differs from that of either original. In classical law, there were two competing points of view. One school of thought, the Sabinians, gave ownership to the owner of the materials. The other school, the Proculians, gave ownership to the maker. The rule under Justinian gave the new thing to the maker only if the materials could not be restored to their original state, or if the maker had himself contributed some portion of the material. The Proculean theory followed Aristotle in favoring essence over matter; the Sabinians followed the Stoics in favoring matter.

3. Art. I, sec. 8 of the Constitution provides that "The Congress shall have power ... to promote the progress of science and useful arts, by securing for limited times to authors and inventors the exclusive right to their respective writings and discoveries." The Constitution thus expressly links Congressional power to grant copyrights with the goal of stimulating authors; the original English copyright law, in contrast, seems to have been intended largely to protect publishers. See B. KAPLAN, AN UNHURRIED VIEW OF CopYright 4-9 (1967). The latter interest apparently dominated the early continental law as well. See Fernay, Grandeur, Misère et Contradictions du Droit d'Auteur, 109 Revue InTERnationale du Droit D'Auteur 139, 141 (1981).

4. The tenn "plagiarism" is used to refer to the subcategory of copyright infringement which involves false designations of authorship and other unattributed uses of copyrighted material. This is usually distinct from the other common subcategory of copyright infringement called "piracy," which involves the production and sale of unauthorized literal copies of a work.

5. See 3 Nimmer, supra note 1 , at $\S 13.01[\mathrm{~A}] ; 17$ U.S.C. $\S 411$ (1982) (registration prerequisite to infringement suit).

6. This is distinct from creating a similar or identical work independently, which is pernnissible. See Selle v. Gibb, 741 F.2d 896 (7th Cir. 1984) (no infringement where evidence of access to prior work insufficient). On copying generally, see 3 NIMMER, supra note 1, at §13.01[B] and $\S 13.02$.

7. See generally 3 Nimmer, supra note 1 , at $\S 13.03$. 
ments, he is entitled to a variety of remedies, including actual damages, a portion of the defendant's profits, statutory damages, and injunctive relief. $^{8}$

This Comment discusses the application of this framework to cases involving musical compositions. Part I explores some particular factual considerations relevant in balancing the interests at stake in cases involving music, and surveys common attitudes in the musical world towards the borrowing of inusical ideas. Part II discusses copying, and exainines some technical considerations important in the comparison of musical works. Part III discusses the issue of "illicit copying"-tlie question of "how much is too much?"-and criticizes two prevalent formulations.

Part IV argues that a better way to balance competing creative imterests would be to focus on rights inore specific than the vague "riglit not to be infringed" which underlies the existing formulations. One of these more specific rights is the right to exploit fully the market for one's creative product, free from competition by works copied from it. ${ }^{9}$ The other is the right to receive compensation for one's creative labor. These rights are already recognized in the existing remedies of actual damages (which protects against injury to the work's market) and apportionment of profits (whicli protects the investment of creative labor). However, Part IV argues that proof of the facts underlying either measure of recovery could largely substitute for the existing metlods of determining illicit copying. In addition, Part IV argues that the scope of the apportionment should be limited to creative contributions to the defendant's work, and should not include noncreative elements of market success.

Finally, Part V argues that injunctive rehef should be granted much more reluctantly than is currently the case. Where there is no probability of actual harm to the plaintiff's market, the presumption should be in favor of a compulsory license. This would balance the plaintiff's right to compensation with the public interest in access to the defendant's creative work.

\section{I}

\section{The Social CONTEXT}

The existing legal framework for copyright actions tends to create perverse incentives through misguided analysis and unclear liability stan-

8. 17 U.S.C. $\$ 502$ (1982) (injunctions), § 504(b) (actual damages and profits), §504(c) (statutory damages). Other measures include impounding and destruction of infringing articles ( $\$ 503)$; costs and attorneys fees ( $\$ 505$ ); and criminal penalties ( 506 and 18 U.S.C. $\S 2319$ (1982)).

9. Cf. Sony Corp. of America v. Universal City Studios, Inc., 464 U.S. 417, 429 (1984) (public benefit is primary concern, but immediate effect is to secure monopoly privileges); Harper \& Row, Publishers v. Nation Enterprises, 471 U.S. 539, 566-67 (1985) ("fair use" doctrine limited to uses which do not materially impair market for imfringed work). 
dards. Plagiarism suits have enormous nuisance value: a defense can cost upwards of $\$ 100,000$ in attorneys fees, in addition to the time lost by musicians in attending depositions and trial instead of in composing, performing, or recording. ${ }^{10}$ This threat may tend to discourage sonne desirable compositional techniques, like the digital sampling and "rap" techniques discussed below. ${ }^{11}$ In addition, the existing law has already worked a tangible disservice on unestablished songwriters. Because of the danger of infringement suits, inany record companies and popular musicians have made it a policy never to listen to or look at unsolicited musical material. ${ }^{12}$

While copying words from another author's book without some form of acknowledgement is generally considered plagiarisin, the inusic world functions according to different social expectations and has done so for centuries. Composers historically have drawn heavily from folk music ${ }^{13}$ and current popular music. ${ }^{14}$ In addition, coinposers often borrow directly from their colleagues. ${ }^{15}$ It is this borrowing from colleagues which is most likely to subject a composer to criticism of his ethics (folk music, in contrast, is generally accepted as legitinate source material. $)^{16}$

Critics delight in spotting and condemning unacknowledged borrowings. ${ }^{17} \mathrm{~A}$ famous example of a composer who received a hostile press for his borrowings is Handel. ${ }^{18}$ Coming to Handel's defense, one biogra. pher writes:

10. See Harrington, Singing All the Way to Court: Charges of Plagiarism Rock the Music World, Washington Post, Sept. 28, 1980, at K1.

11. See infra text accompanying notes 29-30.

12. See Harrington, supra note 10; Going on the Record, Washington Post, Aug. 27, 1984, at C5; Palmer, The Pop Life, N.Y. Times, April 6, 1983, at C14, col. 3.

13. See Bartók, The Infuence of Peasant Music on Modern Music, in CONTEMPORARY COMPOSERS ON CONTEMPORARY MUSiC 72 (E. Schwartz \& B. Childs, eds. 1967).

14. Use of pre-existing material goes back at least to the Renaissance, when Gregorian chants and popular tunes were often used to generate new choral works. An example is the Missa l'Homme Armé (sexti toni) of Josquin Desprez, a late fifteenth century work based on a then-current popular song. A more modern example is Charles Ives's Fourth Symphony (1909-16), which quotes, among other things, "In the Sweet By and By," "Nearer My God to Thee," "Yankee Doodle," "Turkey in the Straw," and "Columbia, Gem of the Ocean." [The date for musical compositions, where given, is that of composition, or if that is uncertain, date of first publication.]

15. See, e.g., N. CARRELl, BACH THE Borrower 227-365 (1967) (listing sources of some of Bach's material).

16. Where folk music is in the public domain, as is usually the case, there is no legal obstacle to its use, although there may be disputes over the resulting rights in the derivative work. See generally, R. BROWN \& R. DENICOLA, CASES ON COPYRIGHT, UNFAIR COMPETITION, AND OTHER Topics Bearing on the Protection of Literary, Musical, and artistic Works 201-02 (4th ed. 1985).

17. See A. Shafter, Musical Copyright 209-15 (2d ed. 1939); Orth, The Use of Expert Witnesses in Musical Infringement Cases, 16 U. PITT. L. REV 232 (1955). These self-styled music critics seem to envision a world full of composers endeavouring mightily to conceal acts of plagiarism, even going so far as to change all the notes.

18. See P. Lang, George Frideric Handel 559-69 (1966). 
We are dealing, of course, with a romantic concept still widely shared by laymen: the composer creates in an intoxicated daze, at 'white heat,' and if he uses material of earlier creation, he is a plagiarist, a swindler, and a thief. One wonders why the otlier romantic conception of the artist as an irresponsible individual who must not be measured by the standards of bourgeois etliics is not apphed in this instance. ... Only those who do not understand the process of musical composition, who cannot see and feel the subtlety of transfiguration that can be created by a clianged melody, even a single note, rhythm, or accent, have made a moral issue of something that is a purely estlietic matter. ${ }^{19}$

Nonmusicians often ascribe an almost magical quality to the invention of musical material. In reality, generating musical material is much less difficult than structuring it. The creation of musical material can be compared to the collection of scientific data, whicli may be time-consuming and require great care, but whicl is still usually within the capabilities of any trained technician. The real gemus lies in the organization and interpretation of the data. Judge Learned Hand recognized this when he wrote, "True, it is the tliemes which catch the popular fancy, but their invention is not where musical genius lies."20

The artistic world has developed its own informal rules for borrowing. ${ }^{21}$ For example, the musical practice in Handel's time, emphasizmg productivity and professional skill over originality of material, permitted borrowing so long as the composer used the material to good effect; the focus was not on the source of the components, but on the quality of the whole. ${ }^{22}$ This attitude dates back to antiquity. Classical writers saw the work of their predecessors as a common fund; ${ }^{23}$ originality was not seen

19. Id. at 560 .

20. Arnstein v. Edward B. Marks Music Corp., 82 F.2d 275, 277 (2d Cir. 1936).

21. Indeed, it might be instructive to admit expert testimony on whether a given borrowing violates the ethical expectations of the parties' colleagues.

22. P. LANG, supra note 18, at 564-65; see also B. KAPLAN, AN UNHURRIED VIEW OF COPYRIGHT 53 (1967). Kaplan advocates "a permissive attitude toward cross-lifting [at least] among serious musical works." Id. (emphasis added). How a court is to distinguish between serious and nonserious works is unclear.

Several nations specifically permit "cross-lifting" in music or other arts. See, e.g., Austria, Urheberrechtsgesetz [UrhG] § 5(2) ("The use of a work in creating another work shall not make the latter an adaptation, provided it constitutes an independent new work as compared to the work used") and $\S 52(1)$ (permitting use of single passages of a published musical work in an independent new musical work); Brazil, Código Civil, lei n. 5.988 of Dec. 14, 1973, art. 50 ("Pastiches and parodies shall be lawful in so far as they are not real reproductions of the work on which they are based and do not discredit it"); Bulgaria, Zakon za avtorskoto pravo, Nov. 16, 1951, $\$ 6$ (neither consent of author nor payment to him required for use of work in the creation of a new, independent work, except for literary-dramatic adaptations) and $\S 7(\mathrm{~b})$ (composers can use literary texts without author's consent, but must pay author a fee upon publication); all translated in UNESCO, COPYRight LAWS AND TREATIES OF THE WORLD (1984).

23. See Seneca, Ad Lucilium Epistulae Morales 12.11 ("What is true is mine... [T] he best ideas are common property."); 16.7 ("Whatever is well said by anyone is mine"); and 79.6 (" $[\mathrm{H}] \mathrm{e}$ who writes last has the best of the bargain; he finds words already at hand which, wheu 
as creation on a blank slate, but rather as a process of selection, reinterpretation, and improvement. ${ }^{24}$ It was only when a writer's use of the fund was uninventive or superficial that he would be taken to task. ${ }^{25}$ Even today, when the financial stakes are higher, good musicians may be disinclined to sue those they consider their equals. ${ }^{26}$ Generally, the big naine in a plagiarisin suit is the defendant's.

One type of borrowing is explicit quotation. Quotations are used extensively in music, ${ }^{27}$ and the professional literature discusses the distinct aestletic function of quotations witlout a hint that such borrowing may be unethical. ${ }^{28}$ A popular modern style using this device is "rap"

marshalled in a different way, show a new face. He is not stealing them . . . when he uses them. They are common property.") (translation by the author of this Comment, based on R. Gummere trans. Loeb ed. 1918).

24. See H.O. White, Plagiarism and Imitation DURING the ENGlish Renaissance 8 (1935) (describing classical practice).

25. See QuinTILIAN, InSTITUTIO ORATORIA 10.2 (H.E. Butler trans. Loeb ed. 1922) ("It is a positive disgrace to be content to owe all our achievement to imitation." Id. 10.2.7); HORACE, ARS Poetica 131-35, and Epistulae i.19.1-34 (in Horace: Satires, Epistles and Ars Poetica, Loeb ed. 1926).

26. For example, it appears that respect for another composer's musical integrity persuaded Michael McDonald of the Doobie Brothers not to sue Robbie Dupree for alleged borrowing. Harrington, supra note 10.

27. See, e.g., Charles Ives, Fourth Symphony (1909-16) (combining various popular tunes in an extensive collage); Luciano Berio, Sinfonia, third movement (1968) (collaging fragments from dozens of pieces and texts, built up over the complete Scherzo of Mahler's Second Symphony); Henri Pousseur, Couleurs croisées (1967) (based on civil rights song "We Shall Overcome"); Karlheinz Stockhausen, Hymnen (1966-67) (national anthems); John Cage, Credo in Us (1942) (record of a piece by Dvorak, Beethoven, Sibelius or Shostakovich-chosen by the performers-becomes part of the ensemble). For a discussion of some of these works and numerous others using pre-existing material, see P. GRiffiths, MOdern Music: THE AVANT GARde SiNce 1945, 188-222 (1981), which includes an extensive repertory listing. "The most obvious technique by which a composer may claim (or deny) roots in the past is that of quotation, and from the time of [Stockhausen's 1966 work] Telemusik the use of quotations, usually from well-known classics of the Western repertory, becomes a cliché of contemporary music." Id. at 200.

28. See, e.g., P. GRIFFITHS, supra note 27, at 200:

[T] he more significant reasons for such borrowings have been those of an aesthetic or even moral order: the need to test the present against the past and vice versa, the desire to improve contact with audiences by offering known subjects for discussion, the wish to find musical analogues for the multiple and simultaneous sensory bombardment in the world.

Griffiths discusses several uses of "pre-formed" musical material, including uses which retain the original musical meaning in a new context (frankly acknowledged quotations), and use as "generative seeds of a totally alien musical development" (integration with the composer's own ideas). Sometimes, the use serves "simply to express, without any deeper qualms of musical conscience, an affectionate respect . . . [or] uninhibited enthusiasm [for the borrowed music]." Id. at 206-07; see also Childs, Time and Music: A Composer's View, 15 PERSPEctives of NEw Music 194, 213 (1977) (comparing use of quotations in works of Charles Ives and George Rochberg, with general discussion of aesthetic effects; one such effect is described poetically as the evocation of "a rich complex of remembrances, with their attendant connotations.")

This lenient attitude towards quotation seems to be a fairly recent development (or re-development). See Peterson, Quotation in Music, 30 MONTHLY MuSICAL ReCORD 217 (1900) (arguing that composers are "debarred" from quoting the great masters); but see id. at 218-19 (where the author catalogs instances of borrowing by Beethoven, Mendelssohn, Schumann and Wagner). 
music, where fragments of recordings are played over and over as the background for the lyrics or "raps." 29 The standard variation form is another common example of the creative use of another composer's material. Although composers of variations are expected to acknowledge the source of the theme, musicians would consider it absurd to give, say, Diabelli rights in Beethoven's Diabelli Variations. Yet the existing legal systein provides little promise that such uses will be secure against an infringement suit.

New technologies also raise copyright problems. Digital sampling, an increasingly popular new technology, involves recyching fragments of sound, often recorded by other musicians. Once the recorded sound fragment is converted from analog to digital form, the resulting stream of numbers (representing the sonic waveform) can be operated on in an infnite variety of ways, altering some parameters (e.g., pitch) while leaving others intact (e.g., timbre). A sinall seed of borrowed sound can, through this technology, generate an entire work; one note from a Coltrane solo could be turned into an extended saxophone quartet. The copyright implications of this compositional tool reinain ambiguous. ${ }^{30}$

Composers may also use inaterial without acknowledgement simply because it suits their needs. This inay involve borrowing a particularly catchy figure $^{31}$ or emulating a popular style. ${ }^{32}$ Composers necessarily listen to other people's music. Composition does not occur in a vacuum. It occurs instead within an artistic culture that includes well-defined techniques and styles, as well as recurrent technical problems. Thus, it is natural that composers take ideas and inspiration froin their colleagues. ${ }^{33}$ In addition, any new piece of music, if it is to be comprehensible to most

29. Some rap pieces have been kept off the market by the threat of copyright suits over a few seconds of material. Pareles, A Prize Question: Who Did What in a Song?, N.Y. Times, April 28, 1988, at B1, col. 1 .

30. See Drake, Digital Sampling: Looming Copyright Problem, UPI, May 8, 1987; Pareles, Ethical Questions Raised by New Music 'Cloning' Technology, N.Y. Times, Oct. 16, 1986, at Y22, col. 1; see also Note, Digital Sound Sampling, Copyright and Publicity: Protecting Against the Electronic Appropriation of Sounds, 87 CoLUM. L. REv. 1723 (1987).

31. An example would be the incessant imitation by subsequent groups of Chuck Berry's guitar riffs, which were themselves "borrowed" from country and western musicians, who in turn had borrowed them from Afro-American music a generation or two earlier. See Christgau, Chuck Berry, in The Rolling StONe IlLuSTRATEd History of Rock \& Roll 54, 55-56 (J. Miller ed. 1980).

32. This is a recurrent theme in the history of popular music. For example, Buddy Holly derived his style from a synthesis of diverse elements including Hank Williams, Hank Snow, Westem swing bands, Elvis Presley, Ray Charles, black gospel, and Baptist Church tunes, and in turn influenced the Everly Brothers, the Beatles, Bob Dylan, Eric Clapton, and Creedence Clearwater Revival. See Cott, Buddy Holly, in The Rolling Stone Illustrated History of Rock \& RolL, supra note 31, at 77, 81; see also Guralnick, Rockabilly, id . at 61, 62-63; Bangs, The British Invasion, id. at 169, 169-70; and Christgau, The Rolling Stones, id. at 190, 192.

33. As Paul McCartney put it, describing the Beatles' work: "We were the biggest nickers in town. Plagiarists extraordinaires." PLAYBOY, Dec. 1984, at 107. 
listeners, must bear at least some similarity to works that have gone before. ${ }^{34}$ In particular, all but the most ground-breaking composers will seek some similarity with other works which are popular or influential at the present. ${ }^{35}$ Music, like clothing, has its fashions.

Because of these fashions, and the desire to assist comprehensibility by familiarity, musical works within a "style" often sound indistinguishable to tlose unfamiliar with the genre. For example, to those unfamiliar witl Baroque harpsicliord music, Tin Pan Alley, 1950's rock ' $n$ ' roll, or Javanese gamelan music, pieces within those styles may all sound alike. Yet to those versed in any of these styles, the differences are readily apparent. The ear moves beyond surface similarities to hear more subtle distmctions. It is in this realm of subtle distinctions that composers work.

On the other hand, there is a strong competing interest in discouraging uncreative, slavisl uses of original music. The public interest is in new artworks, not unoriginal work marketed under another naine. ${ }^{36}$ Uncreative plagiarisin misattributes botll tle novelty of the work and the achieveinent of the plagiarist. ${ }^{37}$ Not only is the original coinposer harmed if the credit for her work is given to another; the public, deprived of knowledge of the true author, is more likely to buy future works of the plagiarist while ignoring those of the artist they actually like.

The balance is a delicate one. To strike it properly, the legal ear needs to listen deeply, sensitive to the way small changes affect a piece of musical material, recognizing that any comparison that fails to probe that deeply will ignore a very large part of tlie compositional process.

34. Some courts have recognized this, albeit cynically: "It must be remembered that, while there are an enormous number of possible permutations of the musical notes of the scale, only a few are pleasing; and much fewer still suit the infantile demands of the popular ear." Darrell v. Joe Morris Music Co., 113 F.2d 80, 80 (2d Cir. 1940).

35. Record producers, in particular, often seek the relative security of investing in proven styles, imitating current hits as closely as possible. See Harrington, supra note 10.

36. Cf. Unless the law recognizes that the same material can be used in different ways, independent creation will be stifled. Nevertheless, there may be limits:

The public should have the opportunity to see what other artists will do with the same plot or situation, after the fashion set by the Greek tragedians. Yet we want to encourage originality and not slavishness. There comes a point where the use of material is so elose [to the original] as not to give the public anything really new. At that point, the ideal of encouraging independent creation ceases to operate.

Chafee, Reflections on the Law of Copyright: I, 45 Colum. L. REv. 503, 514 (1945) (emphasis added).

37. See D. Dutton, Artistic Crimes, in ThE Forger's ART 172, 181 (D. Dutton ed. 1983). 
II

COPYING

\section{A. Copying and Changing}

A critical element of every copyright suit is the determination of whether the defendant copied the plaintiff's work. ${ }^{38}$ This is, first, an inquiry into an historical event: did the defendant make use of the plaintiff's work in creating the allegedly infringing work? Usually, the historical fact of copying is proved by a combination of access to the plaintiff's work by the defendant and similarity between the two works. ${ }^{39}$ Where the direct proof of access is weak, as it often will be, the similarities must be "striking"--similarities too marked to be dismissed as coincidental. ${ }^{40}$ Expert testimony can be used in deciding this question. ${ }^{41}$ Even where there are striking similiarities, of course, evidence of independent creation can overcome the inference of copying. ${ }^{42}$ Copying need not be conscious: at least two famous music copyright cases have held the defendant liable for unconscious copying. ${ }^{43}$

However, even when it is clear that the plaintiff's work was somehow used by the defendant, it will not necessarily be true that the defendant's use can meaningfully be called a "copy." Imagine that a composer produces a song through brute force application of a mechanical process to another song, for example, by playing it in retrograde inversion (backwards and upside-down). It is so unlikely that one song would be the retrograde inversion of another by coincidence that the historical fact of use would hardly be debatable. But should we call the second work a

38. See supra note 6.

39. See 3 NimmER, supra note 1, at $\S 13.01[B]$. See generally Osterberg, Striking Similarity and the Attempt to Prove Access and Copying in Music Plagiarism Cases, 2 J. OF COPYRIGHT, ENT. \& SPORTS L. 85 (1983).

40. See, e.g., Benson v. Coca-Cola Co., 795 F.2d 973, 975 n.2 (11th Cir. 1986) (striking similarity is measured by uniqueness or complexity, and is used to show likelihood of copying; where works are simple, similarity may not prove copying even when average listener would believe works to be the same); Heim v. Universal Pictures Co., 154 F.2d 480, 488 (2d Cir. 1946) ("so idiosyncratic in its treatment as to preclude coincidence"); Stratchborneo v. Arc Music Corp., 357 F. Supp. 1393, 1404 (S.D.N.Y. 1973) ("if only a small, common phrase appears in both . . songs, . . there is no basis for inferring copying, unless the reappearing phrase is especially unique or qualitatively important."); see also Metzger, Name that Tune: a Proposal for an Intrinsic Test of Musical Plagiarism, 34 COPYRIGHT L. SYMP. (ASCAP) 139, 144-47 (1987); Sherman, Musical Copyright Infringement: the Requirement of Substantial Similarity, 22 COPYRIGHT L. SYMP. (ASCAP) 81, 8398 (1977).

41. See, e.g., Baxter v. MCA, Inc., 812 F.2d 421, 424 n.2 (9th Cir.), cert. denied, 108 S. Ct. 346 (1987); Arnstein v. Porter, 154 F.2d 464, 468 (2d Cir. 1946).

42. Selle v. Gibb, 741 F.2d 896, 905 (7th Cir. 1984) (one of two alternative grounds for affirming the district court. The court listed two additional explanations which may overcome the inference of copying: coincidence and common source).

43. See Bright Tunes Music Corp. v. Harrisongs Music, Ltd., 420 F. Supp. 177, 180-81 (S.D.N.Y. 1976); Fred Fisher, Inc. v. Dillingham, 298 F. 145, 147 (S.D.N.Y. 1924). 
copy of the first even though, as will probably be the case, the works do not resemble each other to the ear in any way?

Indeed, every change a defendant makes in the material she uses will alter, to a greater or lesser degree, the resemblance between the two works. Obviously, it makes no sense to call one thing a copy of another unless the two things are in some meaningful sense the same. Imagine a malfunctioning photocopy machine. The act of putting the original on the glass and pressing a button is analogous to the question of copying as historical fact. What goes on inside the inachine, and what comes out the other end as a result, is analogous to what can go on inside the creative mind.

Thus, im addition to hiteral coinparison of musical works, courts should examine the semantic similarity between those works. Semantic similarity refers to the degree to which two compositions resemble each other in effect-the response produced in the listener, or, if you will, the meaning of the work. Technical changes in musical material or its surrounding context may or may not alter the ultimate musical effect. ${ }^{44}$ In music, as in language, small literal changes can have an enormous impact on effect, while conversely, substantial literal changes can leave the original effect largely intact. ${ }^{45}$ To see why this is so, and to understand the elements that can go into the coinparison, a 1nore detailed examination of inusic will be helpful.

\section{B. Comparing Musical Works}

Most discussions of inusic copyright simplistically define music as a coinbination of three "elements": melody, harmony and rhythm. ${ }^{46}$ The

44. A linguistic analogy might be helpful. Take the sentence "The trumpets are loud." If "trumpets" is changed to "ties", the meaning of "loud" also changes; a three-word literal similarity ("The . . are loud") is only a trivial two-word semantic similarity ("The . . . are ..."). Similarly, if the sentence "The trumpets are loud" is used to describe a band concert, it will have a substantially different effect than if it is used to describe a library; in the first case, it is merely an observation, perhaps an approval, whereas in the second it is more likely to be a complaint.

45. See Randall, Two Lectures to Scientists, in Perspectives ON CONTEMPorary Music THEORY 116, 124 (B. Boretz \& E. Cone eds. 1972):

Quite intricate and elaborate musical analysis is required to discriminate between those tiny deviations which are just deviations and those tiny and not-so-tiny deviations which are part and parcel of the projection of an entire musical structure and which are therefore intimately involved in, and qualified by, a complex developing musical context.

46. See, e.g., 1 NIMMER, supra note 1, at § 2.05[D]; A. SHAFTER, supra note 17, at 194-210. French legal thinking has been similarly limited. See C. CARreau, MERITE ET Drort d'AUTEUR 134 (1981) (melody and rhythm protectible, but not harmony alone); H. DEsBots, LE DROIT D'Auteur en France 136-40 (1978); but see M. GaUtreau, LA MusiQue et Les Musiciens EN Drort Prive Français Contemporain 22-24 (1970). The issue, according to Gautreau, is to find "un élément matérial" which is the "réceptacle de la personnalité créatrice du compositeur." The traditional view, which Gautreau attributes to Desbois, is that "the melody will be the locus of the composer's personality" and therefore the embodiment of originality. This view does not comport well with the expanded vocabulary of much modern music: "The element deserving protection, 
following language is, unfortunately, not atypical of the way judges write about music:

Technically analyzed, a musical composition is made up of rhythm, harmony and melody. Originality, if it exists, must be found in one of these. Rhythin, is simply the tempo ${ }^{47}$ in which the composition is written. It is the background for the melody. There is only a limited amount of tempos; these appear to have been long since exhausted; originality of rhythm is a rarity, if not an impossibility. Harmony is the blending of tones; this is achieved according to rules which have been known for many years. Being in the public domain for so long neither rhythm nor harmony can in itself be the subject of copyright.

It is in the melody of the composition-or the arrangement of notes or tones that originality must be found. It is the arrangement or succession of musical notes, which are the fingerprints of the composition, and establislı its identity. ${ }^{48}$

This language is specifically addressed only to the first prong of a copyright action-the protectibility of the plaintiff's material. However, by extension such oversimplification applies to the comparison process as well. If only melody can be original, if inelody is the sole measure of a work's identity, no change which the defendant makes in harmony or rhythm could possibly matter. ${ }^{49}$ In the eyes of the law, such changes would be as irrelevant as changing the color of the paper in our liypothetical photocopier. ${ }^{50}$ Sucl an analysis ignores two crucial facts about music. First, music is made up of many inore "eleinents" than these.

directly constituting the creation's originality, is a function of the technical work of compositionthat is, essentially variable according to the nature of the work." GAUTREAU, supra at 22-24 (translation by the author of this Conment).

47. This is incorrect. Rhythm refers to proportional time values, e.g. quarter notes and eighth notes, whereas tempo refers to actual time values, e.g. specifying that a quarter note is to last one half of one second ((footnote by author of this Comment) (not in original)).

48. Northern Music Corp. v. King Record Distributing Co., 105 F. Supp. 393, 400 (S.D.N.Y. 1952).

49. See the discussion of Judge Learned Hand's early analytic practice, infra note 60 .

50. An exclusive focus on melody, harmony, and rhythm also leads to the assumption that the possibilities for originality in music are substantially linited. See, e.g., A. SHAFTER, supra note 17 at 194-97 (mistakenly asserting that unusic is straight-jacketed by limited vocal ranges, the limited nunber of tones, etc.) According to Shafter, "[p]ractically every original idea the composer can think of has appeared somewhere before; it is a matter of probabilities, and every day the number of new possibilities grows less." Id. at 196. A diametrically opposite position is taken by most musicians and philosophers. See, e.g., Cox, Are Musical Works Discovered?, 43 J. AESTHETICs \& ART CRITICISM 367, 370 (1985) ("a seemingly infinite array of possible choices involved in the compositional process"); cf. Levinson, What a Musical Work Is, 77 J. of PhIL. 5, 10 (1980) (because musical works are different if produced at different times or places, or by different individuals, there are infinitely many different works).

New technologies and new ways of thinking about music, including exposure to other musical cultures, actually increase the palette available to composers. Some American legal writing has recognized the need of copyright to respond to this expansion of the musical universe. See, e.g., Goldstein, Copyrighting the New Music, 16 COPYRIGHT L. SYMP. (ASCAP) 1 (1968); and Nelson, Jazz and Copyright: $A$ Study in Improvised Protection, 21 CopYRIGHT L. SYMP. (ASCAP) 35 (1974). 
Second, originality is better viewed as a function of the interaction and conjunction of these elements than of any element alone; a change in one element necessarily affects our perception of all others. These two facts will be discussed in turn.

Several elements besides melody, harmony and rhythm are often important structurally. Timbre ${ }^{51}$ is one obvious example of an element commonly used creatively by composers and discussed by theoreticians. ${ }^{52}$ Spatial organization is yet another. ${ }^{53}$ There are many highly original compositions which would lose much of their protection if copyright did not extend to such elements. Since the 1950's, popular songs have moved beyond an exclusive focus on melody, chords and lyrics, to a more imaginative use of rhythm, phrasing, bass lines, instrumentation and new technological effects, all of which can play an important role in a song's originality. Specific works may manipulate elements quite difficult to categorize. ${ }^{54}$ Even melody, harmony and rhythm are not as lim-

51. Timbre is the tonal quality of a sound. For example, a piano and a harpsichord sounding the same pitch produce different timbres. This tonal quality derives mostly from a sound's overtones; the envelope (attack, decay, sustain and release) of a sound may also influence timbre. Works heavily dependent on timbre include Claude Debussy's Prélude à l'après-midi d'un faune (1895); Amold Schoenberg's Five Pieces for Orchestra, op. 16 (1908) (an carly use of Klangfarbenmelodie-“melody of tone colors"); Karlheinz Stockhausen's Mikrophonie I (1964) (work for single tain-tain and six performers using microphones, filters and potentiometers); and Paul Lansky's Fantasies on a poem by Thomas Campion (1982) (digital alteration of human speaker's voice to create timbral shifts and "new" instruments).

Timbre receives indirect protection in some cases via 17 U.S.C. $\$ \S 106(2)$ and 103(b), which protect "derivative works," defined in $\S 101$ to include "musical arrangement[s]." An arrangement includes the creation of a new timbre structure for a pre-existing work.

52. See, e.g., R. ERICKSON, Sound StRuCTURE IN Music (1975); Cogan, Toward a Theory of Timbre: Verbal Timbre and Musical Line in Purcell, Sessions, and Stravinsky, 8 PERSPECTIVES OF New Music 75 (1969); Varèse, The Liberation of Sound, in CONTEMPORARY COMPOSERS ON CONTEMPORARY MUSIC, supra note 13, at 194.

53. See, e.g., Brant, Space as an Essential Aspect of Musical Composition, in CONTEMPORARY COMPOSERS ON CONTEMPORARY MUSIC, supra note 13, at 222; and Varèse, The Liberation of Sound, supra note 52, at 204-07. Noteworthy uses of space include the Canzonas and Sonatas of Giovanni Gabrielli (sixteenth century works written for the special acoustics of St. Marks); Hector Berlioz's Requiem (1837) (brass groups positioned in four groups in balcony); Charles Ives's The Unanswered Question (1906); and Karlheinz Stockhausen's Sternklang (1976) (five groups of musicians distributed throughout park).

54. Karlheinz Stockhausen gives four examples from electronic music: "the correlation of the coloristic, harmonic-melodic, and metric-rhythmic aspects of composition"; "the composition [construction] and de-composition of timbres"; "the characteristic differentiation among degrees of intensity"; and "the ordered relationships between sound and noise." Stockhausen, The Concept of Unity in Electronic Music, in Perspectives ON CONTEMPORARY Music TheORY 214 (B. Boretz \& E. Cone, eds. 1972). The key word in the first example is correlation:

Work in the [electronic music] studio had brought [Stockhausen] to an appreciation of what he called the 'unity' of electronic music. A pitched note would, when slowed down to below about [ 16 cycles per second], begin to be perceived not as a tone but as a regular rhythmic beat, with subsidiary rhythms contributed by the frequency components which had given it its timbre. If slowed down still further, a single note could become a whole musical form. Thus the four basic constituents of music-pitch, timbre, rhythm and form-could all be seen as facets of the same phenomenon, that of vibration. 
ited as judicial opinions would have us believe: rhythmic possibilities have expanded enormously in the last century, ${ }^{55}$ and composers have experimented with microtonal pitch systems and different systems of tuning. ${ }^{56}$

In order to be protected, different musical elements may have to be used in more specific ways than others. For example, a composer's clioice of instruments to be used in a particular piece sliould not be protectible $^{57}$ even if the combination is urique; otherwise tlie composer would be pre-empting too broad an area, like a novelist's choice of a particular time or place for a setting, which likewise is not copyrightable. However, tlie details of the ways the instruments are used-sequences and combinations of timbres at a note-by-note level-are more analogous to the interplay of characters and events in a novel, and may be original and specific enough to support a claim of infringement. Similarly, a composer working in electronic or computer music sliould not be able to claim a copyright in specific timbres she "discovers," but only in her structural use of them.

The second point, tliat originality is more likely to be found in tlie interraction and conjunction of elements tlian in the elements themselves, requires a more detailed discussion. An example will illustrate the problem. Compare the following two musical phrases:

P. GRiffiths, A ConCISE History of AVANT-GARDE Music From Debussy to Boulez 159-60 (1978). Stockhausen first made use of this theory in Kontakte (1959-60).

55. See, e.g., H. Cowell, excerpt from New Musical Resources, in CoNTEMPORARY CoMposers on CONTEMPORARY MUSIC, supra note 13, at 135. The unique player-piano pieces of Conlon Nancarrow, composed by hand-punching piano rolls, are significant mid-century explorations of complex rhythms, as is much of the music of Stockhausen, Pierre Boulez and Krzysztof Penderecki. Another direction is the use of aleatoric rhythms by John Cage, and the use of echo as a rhythmic element in Stuart Dempster's record Stuart Dempster in the Great Abbey of Clement VI (1750 Arch Records 1976). An example of what computers can do is Joel Gressel's Points in Time (Odyssey Y $34139,1976)$.

56. See, e.g., F. Busoni, excerpt from Sketch of a New Esthetic of Music, in CoNTEMPORARY COMPOSERS ON CONTEMPORARY MUSIC, supra note 13, at 4, 12-15 (early twentieth century discussion of microtonal systems); H. PARTCH, GeNesis OF A MUSIC (1949). Harry Partch's music is probably the single most important oeuvre of Western microtonal music.

57. But see K. Stockhausen, record jacket notes for Momente, Nonesuch H-71157, drawn from Stockhausen's Texte I \& II, Cologne (1963 \& 1964), and from the composer's commentary for the performance of Momente at the Donaueschinger Musiktage, October 1965:

The unique and non-transferable composition of one's sound material is to my mind just as important today as for example the selection of themes, motives, and formal schemes was in earlier compositions .... I also feel, therefore, that the specific selection and combination of an instrumental force for a particular work should remain unrepeatable and uncopyable, both for myself and for other composers. 
Example $A^{58}$

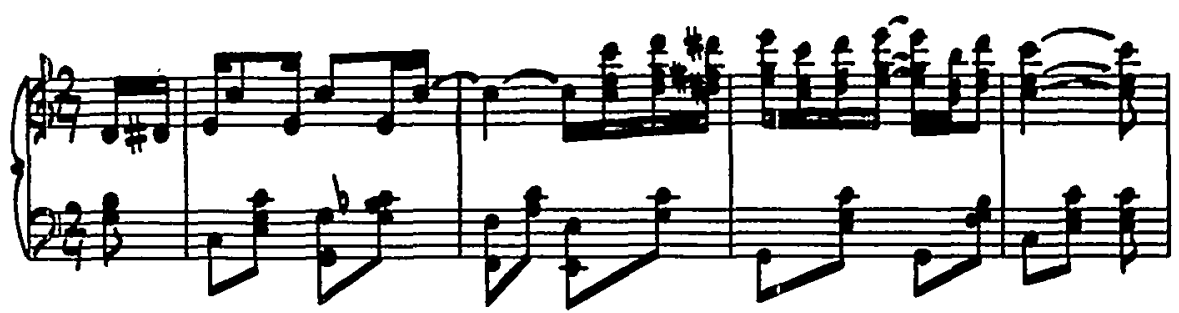

Example $B^{59}$

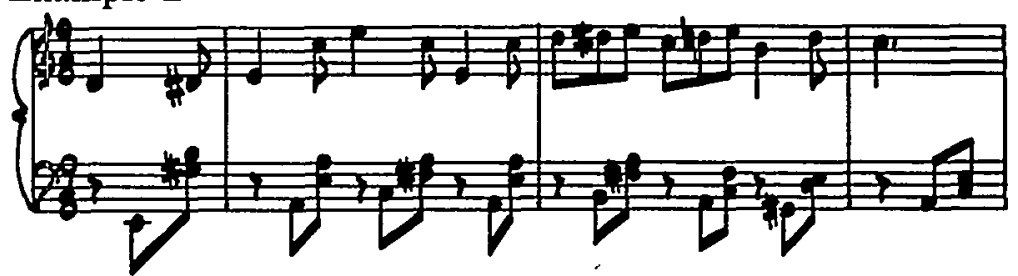

No listener is likely to find these two musical phrases identical, nor even particularly similar. Yet an analysis of only the pitches in the melody, ignoring the harmony and rhythm, would find virtually no difference between these phrases. ${ }^{60}$ One reason these phrases sound different is that we, as musical listeners, tend not to hear merely acoustical sounds per se, but rather structural relations among sounds. A change in any element can alter these structural relations. This can be seen by analyzing the succession of vertical relationships in our two examples:

\section{Example A}

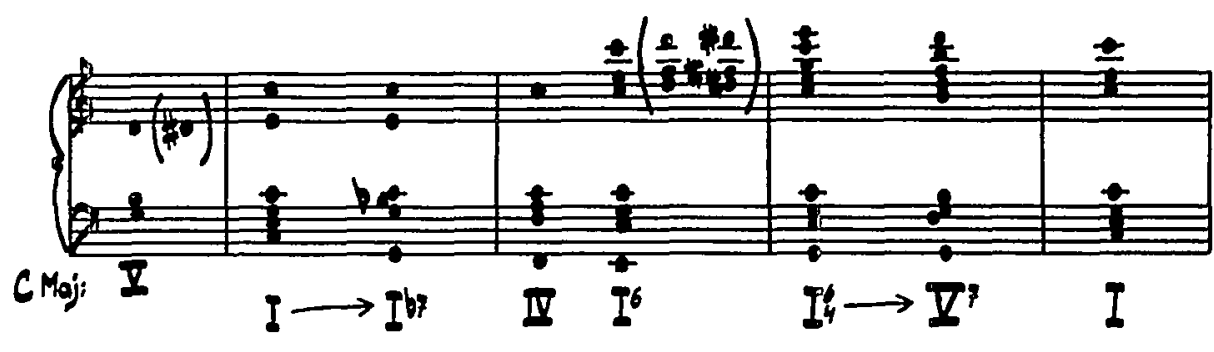

58. Scott Joplin, The Entertainer mm. 4-8 (1902).

59. The Plagiarist mm. 4-8 (by the author).

60. The pitches in the melody of each example are: D D\# E C E C E C [C] D D\# E C D E B D C. Octave displacement was used in Example B-for example, the sequence beginning C D D\# $\mathbf{E}$ is one octave lower in example $\mathbf{B}$.

This simplistic type of comparison was used by Judge Learned Hand in some early cases. See, e.g., Hein v. Harris, 175 F. 875 (C.C.S.D.N.Y.), aff'd, 183 F. 107 (2d Cir. 1910). His method consisted of "either changing the rhythm of the infringing song [actually, just the tunel to the time value of plaintiff's tune or assigning equal [time] value to all notes . . . [and then] comparing the notes in each song bar by bar." Orth, The Use of Expert Witnesses in Musical Infringement Cases, 16 U. PITT. L. REV. 232, 235 (1955). For a detailed criticism of this procedure, see Sherman, supra note 40 , at $130-34$. 
Example B

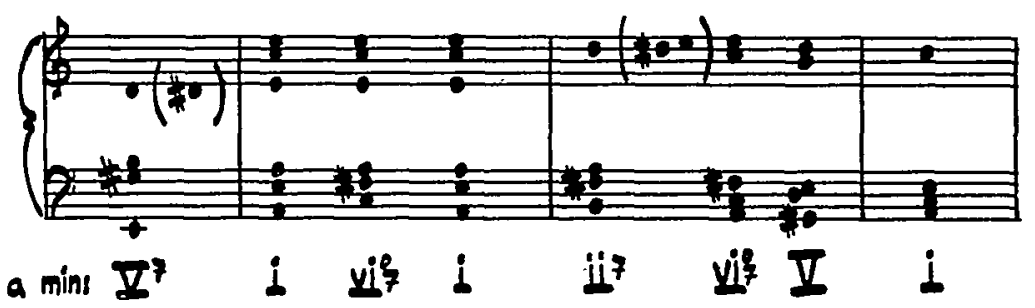

How, then, do we determine whether example B is a "copy" of example A? The determination depends on defining the identity of each exainple and measuring their similarity. ${ }^{61}$ Unfortunately, neither task is simple. Defining the identity of a piece of music is a difficult ontological problem over which theorists violently disagree; from this difficulty, difficulties in ineasuring similarity necessarily follow.

The problem is usually posed by music theorists and aestheticians in this way: Assume that a musical score is in front of me on my music rack. Attempting to perform it, I make several mistakes im pitch or rhythm. Have I performed the music described in the score? In other words, how far can I deviate from the notated work without changing its identity?

Perhaps the strictest definition of identity is given by Nelson Goodman. He defines a correct performance as one which observes "complete compliance with the score." ${ }^{2}$ One wrong note would make the music played a different piece than that described by the score. ${ }^{63}$ Although this definition may be useful in the context of strict ontological discourse, ${ }^{64}$ it would mean in practice that a change of one note in Beethoven's Ninth would entitle the note-changer to present the result under his own name

61. The ability to measure degrees of similarity is important legally both to apportionment of profits and to the availability of injunctive relief. When two works, or parts thereof, are similar but not identical, there is necessarily a quantum of originality added by the second composer. As this quantun increases, the plaintiff will be entitled to a smaller portion of profits, and the equities favoring an injunction may be less.

62. N. Goodman, LANGUAGes of ART 186. See generally id. at $179-92$ (2d ed. 1976).

63. Id. at 186-87. For a succinct criticism of this position, see Ziff, Book Review, 80 Phil. REv. 509, 513-15 (1971).

64. N. GoodMAN, supra note 62, at 186-87:

The innocent-seeming principle that performances differing by just one note are instances of the same work risks the consequence-in view of the transitivity of identity-that all perfornances whatsoever are of the same work. If we allow the least deviation, all assurance of work-preservation and score-preservation is lost; for by a series of one note errors of omission, addition, and modification, we can go all the way from Beethoven's Fifth Symphony to Three Blind Mice.

In one plagiarisin trial, defendant Dolly Parton demonstrated how "you can make things sound like other things" by singing the Ray Charles song "I Can't Stop Loving You" in the same style as " 9 to $5 "$ (the song of hers at issue). UPI, 12/13/85. 
as a new artwork. This definition is obviously too extreme for practical legal purposes.

Benjamin Boretz, responding to Professor Goodman, ${ }^{65}$ offers a inore practical theory. Professor Boretz argues, in general, that the identity of a piece of music is its perceived ${ }^{66}$ structure, which he terms its "coherence." ${ }^{67}$ According to Boretz:

Sounds ... are not part of music, however essential they are to its transmission. . . . Sounds, in fact, are not even what musical notation specifies. . . . What scores do specify is information about music-structural components, such as pitches, relative attack-times, relative durations [etc.] ${ }^{68}$

The inore precise the score as to a particular coinponent, for example pitch, the more determinate the resulting interpretation, and the closer the defendant's use of that coinponent will probably have to be for it to be perceived as a copy. Furthermore, custons of specificity in musical notation interact with acquired histening habits to affect the way music is performed and perceived. ${ }^{69}$ For exainple, histeners from a musical culture with a greater einphasis than ours on minute pitch fluctuations might beheve two performances of Beethoven's Ninth to be fundamentally different compositions if their increased focus on pitch fluctuations caused thein to hear differences that Western listeners, if they noticed thein at all, would dismiss as irrelevant tuning problems. Similar but less extreine differences of einphasis also occur among listeners and works within a specific musical culture.

As a result, any structural description of a work, any attempt to define its identity, will interpret soine deviations from the score as more serious than others. In other words, since a musical work is a structural coherence realized in sound, the important thing is what the sounds do, how they are used, rather than what they are in acoustical terms. ${ }^{70}$ This is why it cannot suffice simply to count the nuinber of changed notes to

65. B. Boretz, Nelson Goodman's Languages of Art from a Musical Point of View [hereinafter Boretz], in Perspectives on Contemporary Music Theory 31 (B. Boretz \& E. Cone eds. 1972).

66. "[An interpretive, analytical] system [is] a mode of cognition rather than an invariant attribute of data-complexes," i.e., analysis describes perceptions rather than sounds, and, as a subjective process, is itself creative. Boretz, Musical Cosmology, 15 PERSPECTIVES OF New MUSIC 122, 128 (1977); cf. Martin, Modes of Explanation in Analytical Discourse, 15 PERSPECTIVES of NEW MUSIC 174, 183-88 (1977) (criticizing over-emphasis on cognitive formulations, and arguing that, through metaphor, we can talk about works themselves, and not just our perceptions of them, in a way which goes beyond mere acoustical description.)

67. BORETZ, supra note 65 , at 33 .

68. Id. at 34 (emphasis omitted).

69. Id. at 35 .

70. As one writer puts it, "A melody is a series of tones that makes sense." V. ZuCKERKANDL, SoUND AND SYMBOL 15 (W. Trask trans. 1956). Thus, any inquiry into copying needs to explore the sense as well as the series. 
determine the degree of difference between two works. ${ }^{71}$

The sort of structural coherence referred to here should not be misunderstood as equivalent to the familiar large-scale structures of a musical work, such as sonata form or the repetitive pattern of a popular song. Musical structural analysis probes much deeper; it is possible, at least in theory, to describe the strnctural function of every sound in a piece. Much music theory, especially tonal theory, ${ }^{72}$ is reductionist in that it suggests a hierarchy of notes within a piece; at each level of analysis more notes are excluded as ornamental, until at the highest level only a short, abstract pitch-structure remains. ${ }^{73}$ Such a theory of music is consistent with Learned Hand's famous "abstractions" test:

Upon any work . . . a great number of patterns of increasing generality will fit equally well, as more and more of the incident is left out. The last may perhaps be no more than the inost general statement of what the [work] is about ... but there is a point in this series of abstractions where they are no longer protected, since otherwise the [artist] could prevent the use of his "ideas," to which, apart from their expression, his property is never extended. ${ }^{74}$

Of course, this test works equally well in the opposite direction: no protection is available at the level of individual sounds or small groups of sounds, either. Drawing the hine on either side-to exclude from protection both the too specific and the too general-is problematic.

To summarize: We have seen that a composer creates something more than a string of acoustical events. Rather, the thing created is best viewed as a structure of relationships. Because the sounds in a composition are dependent on one another for their meaning, musical meaning is solely a function of context. Thus, preservation of context must be a crucial element of copying. It is not enough to compare only strimgs of acoustical events. The comparison must include the structures that the sounds articulate. It is only in giving meaning to sounds that a composer can be said to have created something worthy of protection. Indeed, composers do not create sounds at all; they create only musical structures which are revealed through sound. When a composer places the sounds used by another composer in a new context (where they articulate a different structure), nothing created by the first composer has been taken.

71. BORETZ, supra note 65 , at 36 .

72. Tonal theory describes music organized around a tonal center, for example, virtually all Western music composed before 1900 , and much written thereafter, mcluding all popular and commercial music.

73. This is the gist of Heinrich Schenker's theory, set forth in his book FrEE CoMPOSITION (E. Oster ed. 1979). Examples of applications of this theory can be found in H. SCHENKER, FIVE Graphic Music ANalyses (Dover ed. 1969).

74. Nichols v. Universal Pictures Co., 45 F.2d 119, 121 (2d Cir. 1930), cert. denied, 282 U.S. 902 (1931). 
Therefore, it would be troublesome to assert that these sounds, as they appear in the second composer's work, are still the property of the first.

What makes the matter difficult is that virtually any change, either to the borrowed passage itself or to the surrounding context, will alter the meaning of the passage to some extent. Courts must thus decide not only how much material must be taken, but also how much of its meaning must survive the transfer from the plaintiff's work to the defendant's in order for the defendant to be held liable for infringement. The judicial attempts to answer these difficult questions are discussed in the next Part.

\section{III \\ ILLICIT COPYING}

As a threshold matter, the reader should always keep in mind an important distinction. Some copying is not infringing because what is copied is not protectible at all-for example, a single interval (too specific) or a large-scale forinal scheme (too general). Other copying may not be infringing because, although the defendant did use something protectible (for example, a melody), he nevertheless took so little from the plaintiff's work, or changed what he took so much, that he should not be held hable. In the first case, the nature of the plaintiff's material is the crucial concern; in the second, the nature of the defendant's use. The latter situation is the one to which this Comment is primarily addressed.

In the present scheme of things, after the plaintiff proves the bare issue of use as an historical fact, the court next asks whether there has been "illicit copying"- that is, whether so much has been copied that hability should attach. It is only after hability has been determined that the court proceeds to the question of remedies. These can include actual damages, disgorgement of profits, statutory dainages, and injunctions. ${ }^{75}$ Because statutory damages can be awarded even without a showing of specific harm, ${ }^{76}$ the determination of liability, alone, is enough to subject the defendant to a monetary penalty. This Comment suggests a different framework, but first it is necessary to describe how the current system works and what its problems are.

The question of "illicit copying" is perhaps the hardest in copyright law. Many cases and commentators have grappled with it. ${ }^{77}$ No doctrine has, as yet, clearly prevailed, and a complete discussion of the various

75. See supra note 8.

76. 17 U.S.C. $\S 504(c)(1)(1982)$.

77. See, e.g., 3 NiMMER, supra note 1, at § 13.03; Barry, Toward a Model for Copyright Infringement, 33 COPYRIGHT L. SYMP. (ASCAP) 1 (1987); Metzger, supra note 40; Sherman, supra note 40; Sorensen \& Sorensen, Re-Examining the Traditional Legal Test of Literany Similarity: A Proposal for Content Analysis, 37 CORNELl L.Q. 638 (1952); and cases cited therein; Note, Copyright Infringement Actions: the Proper Role for Audience Reactions in Determining Substantial Similarity, 54 S. CAL. L. REv. 385 (1981). 
doctrines would be beyond the scope of this Comment. A brief discussion of two leading formulations will suffice for our purposes.

One classic formulation, expressed most familiarly in Arnstein $v$. Porter,$^{78}$ focuses on the value to the plaintiff's work of the material taken from it. The more "valuable" the material taken, the more likely that the taking will be found to be "too much."79 The value of the borrowed inaterial to the defendant's work is ignored in determining hability. As a rule of quantitative analysis, this prevents a defendant from appropriating a five-minute song for use in a four-hour opera, ${ }^{80}$ but would seem, conversely, to allow the defendant to market as his own a five-mmute aria out of a plaintiff's four-hour opera. In qualitative analysis, too, the focus is on the value of the material to the plaintiff's work. In one early case, two songs used the same six notes to set the words "I hear you calling ine." ${ }^{81}$ The plaintiff sought a preliminary injunction, which the court granted (waivable upon issuance of a bond), writing:

Sitting for the inoment as the uninformed and technically untutored public, the main thing that impressed me was the plaintive "I hear you calling me" in both songs. I (the public) really was not much concerned as to the details of the [two songs]. The "I hear you calling me" has the kind of sentiment in both cases that causes the audiences to listen, applaud, and buy copies in the corridor on the way ont of the theater..$^{82}$

One commentator has read this language to hold that the substantial similarity test protects "the portion of the plaintiff's work that makes it valuable-artistically and commercially": in other words, the "catchy

78. 154 F.2d 464 (2d Cir. 1946). See infra, text accompanying notes 84-85.

79. See 3 NiMMER, supra note 1, at $\S 13.03$; Sherman, supra note 40, at 92; see also, Elsmere Music, Inc. v. NBC, 482 F. Supp. 741,744 (S.D.N.Y.) ("heart of the coinposition"), aff'd per curiam, 623 F.2d 252 (2d Cir. 1980); Bright Tunes Music Corp. v. Harrisongs Music, Ltd., 420 F. Supp. 177, 178 n.6 (S.D.N.Y. 1976) ("essential musical kernal"); Robertson v. Batten, Barton, Durstine \& Osborn, Inc., 146 F. Supp. 795, 798 (S.D. Cal. 1956) ("that portion of [plaintiff's work] upon which its popular appeal, and, hence, its commercial success, depends."); Northern Music Corp. v. King Record Distrib. Co., 105 F. Supp. 393, 397 (S.D.N.Y. 1952) ("the whole meritorious part of the song"). But see MCA, Inc. v. Wilson, 425 F. Supp. 443, 449-51 (S.D.N.Y. 1976) (lengthy discussion of similarities between works without mention of value to plaintiff's work. Note that the court's discussion of substantial similarity hardly differs from its prior discussion of copying, $i d$ at 447-49: "Our disposition of the [substantial similarity issue], directly and logically follows from our prior determination that the former was copied in substantial part from the latter." Id. at 449), aff'd in part and modified in part, 677 F.2d 180 (2d Cir. 1981). English law also emphasizes the quality of what was taken. See Ladbroke (Football) Ltd. v. William Hill (Football) Ltd. [1964] 1 W.L.R 273, 276.

80. Cf. Sherman, supra note 40 , at 102-03. Sherman's analysis hinges on whether the appropriated portion is sufficiently large to be considered equivalent to the plaintiff's work as a whole. However, just as it could lead to unfair results to compare the size of the plaintiff's and the defendant's work, it is also problenatic to compare the size of the portion taken with the whole. Such an approach would necessarily give less protection to longer works.

81. Boosey v. Empire Music Co., 224 F. 646 (S.D.N.Y. 1915).

82. Id. at 647 . 
part."83

The court in Porter defined the question of illicit copying as:

whether defendant took from plaintiff's works so much of what is pleasing to the ears of lay histeners, who comprise the audience for whom such popular music is composed, that defendant wrongfully appropriated something which belongs to the plaintiff. ${ }^{84}$

The court viewed the effect of the copied material on the jury-sitting in for the lay audience-as a way to infer dainage to the plaintiff's market: "The plaintiff's legally protected interest is not, as such, his reputation as a musician but his interest in the potential financial returns from his compositions which derive from the lay public's approbation of his efforts." 85

In cases where there is reason to suspect that the defendant's use is damaging the plaintiff's market-for example, where her song appears at about the same time as the plaintiff's-this test creates a presuinption that is probably vahi: appropriation of the catchy part is likely to result in appropriation of the plaintiff's customers as well. A recognizable use by the defendant of the most appealing part of the plaintiff's work is necessary, and will often be sufficient, for the audience of consumers to treat the defendant's work as a market substitute for the plaintiff's. But the Porter formulation is unsatisfactory in two respects.

First, Porter should not be read to limit recovery to situations where market dainage is provable. ${ }^{86}$ Such a reading would be inconsistent with the fundamental tenet of copyright law that value-aesthetic or cominercial-is not a factor which the legal system can properly take into account in extending protection. ${ }^{87}$ Under a strict reading of Porter, extensive literal use of relatively dull material would go unpunished, so long as the "valuable" portions were not appropriated. In addition, such

83. Sherman, supra note 40 , at 106.

84. 154 F.2d 464, 473 (2d Cir. 1946).

85. Id. Although the Porter court refused to recognize the importance to an artist of his reputation, courts are gradually acknowledging this concern. See, e.g., Gilliam v. American Broadcasting Cos., 538 F.2d 14, 19 (2d Cir. 1976). Reputation has long been protected under French law. See H. DesBois, LE Droit D'AuTEur EN France 469-561 (1978).

86. Many cases have awarded recovery where the only apparent economic injury was the loss of a licensing fee from the defendant. See, e.g., Litchfield v. Spielberg, 736 F.2d 1352 (9th Cir. 1984), cert. denied, 470 U.S. 1052 (1985); Reyher v. Children's Television Workshop, 533 F.2d 87 (2d Cir.), cert. denied, 429 U.S. 980 (1976); Sheldon v. Metro-Goldwyn Pictures Corp., 81 F.2d 49 (2d Cir.), cert. denied, 298 U.S. 669 (1936); MCA v. Wilson, 425 F. Supp. 443 (S.D.N.Y. 1976), aff'd in part and modified in part, 677 F.2d 180 (1981); Sayers v. Spaeth, 20 Copy. Dec. 625 (S.D.N.Y. 1932); and Fred Fisher, Inc. v. Dillingham, 298 F. 145 (S.D.N.Y. 1924).

87. See 17 U.S.C. $\$ 102$ (1982); Bleistein v. Donaldson Lithographing Co., 188 U.S. 239, 250 52 (1903); Alfred Bell \& Co., Ltd. v. Catalda Fine Arts, Inc., 191 F.2d 99 (2d Cir. 1951). French law also excludes quality (mérite) from consideration in granting copyright protection. CoDE CiviL, loi du 11 mars 1957, art. 2 (83e ed. Petits Codes Dalloz 1983). This exclusion is based in part on the incompetence of judges to make aesthetic distinctions. See C. CARREAU, MERITE ET DroIT D'AUTEur 42 (1981). 
a rule would fail to protect the plaintiff's distinct interest in being coinpensated for the use of her creative labor. ${ }^{88}$

Second, in failing to consider the effect of changes the defendant may have made in the plaintiff's inaterial, Porter does not fully answer the question of how inuch copying is enough to incur hability. For example, the retrograde-inversion hypothetical presented earlier would trigger liability under the Porter test if it involved the catchy part of the plaintiff's work, even if, after the transformation, it no longer sounded so catchy. The Porter language is best viewed not as a way of drawing lines, but rather as an acknowledgeinent that plaintiffs are protected against provable or probable market dainage. ${ }^{89}$

Another formulation of illicit copying has its origin in the so-called idea-expression dichotoiny. ${ }^{90}$ The Copyright Act of 1976 adopted, perhaps unfortunately, the judicially-created distinction between "expression" and "idea". 91 Under this schene, a determination of illicit copying requires separating "ideas," which are not protected, from "expression," which is. ${ }^{92}$ This distinction, supposedly, "accurately conceptualizes the fundamental elements in an artistic creation and balances the competing interests inherent in the copyright law." 93

This is the theory of the leading Ninth Circuit case Sid \& Marty Krofft Television Productions, Inc. v. McDonald's Corp. ${ }^{94}$ The court split the copying issue into an "extrinsic test," which rehes on specific criteria and expert analysis to determine if there is "substantial similarity in ideas," and an "intrinsic test," which relies on the subjective responses of

88. See infro text accompanying notes 122-63.

89. The subsequent application and occasional misunderstanding of Porter is described in Barry, supra note 77 , at 14-29.

90. The idea-expression dichotomy is discussed in 1 NIMMER, supra note 1 , at $\S 2.03[\mathrm{D}]$ and 3 NIMMER § 13.03[A][1]. According to Nimmer, this dichotomy is "not so much a limitation on the copyrightability of works, as it is a measure of the degree of similarity which must exist as between a copyrightable work and an unauthorized copy, in order to constitute the latter an infringement." Id. at $\$ 2.03[\mathrm{D}]$; see Sid \& Marty Krofft Television Prods., Inc. v. McDonald's Corp., 562 F.2d 1157, 1162-69 (9th Cir. 1977) (idea and expression are distinct elements which must be "distilled" from one another); see also Whelan Assocs. v. Jaslow Dental Laboratory, Inc., 609 F. Supp. 1307, 1320-21 (D. Pa. 1985) (alleged infringement of computer program; opinion suggests that idea-expression boundary varies from one medium to another), aff'd 797 F.2d 1222 (3d Cir. 1986), cert. denied, 107 S. Ct. 877 (1987).

91. 17 U.S.C. $\$ 102(b)$ (1982).

92. See, e.g., Nichols v. Universal Pictures Corp., 45 F.2d 119, 121 (2d Cir. 1930), cert. denied, 282 U.S. 902 (1931). The relevant language is quoted supra text accompanying note 74. Although only "expression" can be protectible under this theory, one line of cases has held that substantial similarity analysis of artistic works requires looking at all elements of the work, including uncopyrightable elements. See McCulloch v. Albert E. Price, Inc., 823 F.2d 316, 320 (9th Cir. 1987); Roth Greeting Cards v. United Card Co., 429 F.2d 1106, 1109 (9th Cir. 1970).

93. Sid \& Marty Krofft Television Prods., Inc. v. McDonald's Corp., 562 F.2d 1157, 1163 n.6 (9th Cir. 1977).

94. 562 F.2d 1157 (9th Cir. 1977). 
ordinary reasonable people to see if there is "substantial similarity in expressions." 95 Infringement is proven only when both prongs are satisfied. In no case, however, is it necessary to prove that the defendant took "what is pleasing" in the plaintiff's work. The aesthetic element is correctly left out.

The Krofft test, formulated in a case involving characters, was held applicable to music cases in Baxter v. $M C A$, Inc. ${ }^{96}$ In that case, the plaintiff claimed that John Williams had infringed the plaintiff's song "Joy" in composing the "Theme from E.T." The defendants, on motion for summary judgment, conceded access and substantial similarity of ideas, but insisted there was no substantial sinilarity of protectible expression..$^{97}$ The district court granted the motion, but the Ninth Circuit reversed and remanded for trial, holding only that "reasonable minds could differ" as to the presence or absence of substantial similarity of expression. ${ }^{98}$

The Baxter court recognized that "[d]eterminations of substantial similarity of expression are subtle and complex,"99 and that "no bright hine rule exists" 100 for this determination. In spite of this complexity, " '[a]nalytic dissection' and expert testimony are not called for; the gauge of substantial similarity [of expression] is the response of the ordinary lay hearer." 101 However, expert testimony is admissible "as to the substantial similarity of general ideas as between the two works."102 The opinion is silent as to how these elements are to be distinguished in determining the evidentiary issue. In evaluating the defendant's argument that the similarity between the two works involved too small a sequence-only six notes, according to the defendants-the Court applied the "plamtiff's value" test: "Even if a copied portion be relatively small in proportion to the entire work, if qualitatively important" there is infringement. ${ }^{103}$ The jury would be allowed on remand, however, to find the similarity "insubstantial." 104

The problem with applying the Krofft-Baxter analysis to music copyright cases is that however elegant the distinction between idea and expression may seem as a matter of legal theory, empirically it is an

95. Id. at 1164; see also, Litchield v. Spielberg, 736 F.2d 1352, 1357 (9th Cir. 1984), cert. denied, 470 U.S. 1052 (1985), applying the Krofft analysis: "To constitute infringement of expression, the total concept and feel of the work must be substantially similar."

96. 812 F.2d 421 (9th Cir. 1987), cert. denied, 108 S. Ct. 346 (1987).

97. Id. at 423 .

98. Id. at 425 .

99. Id. at 424 .

100. Id. at 425 .

101. Id. at 424 .

102. Id. at 424 n.2.

103. Id. at 425 (emphasis added).

104. Id. 
impossible distimction to make. ${ }^{105}$ In music there is no "idea" or "expression" to be distinguished. The conceptual framework simply has no relationship to the type of artwork involved. The difficulty can be seen by trying to apply the distinction to any familiar piece of music, or to the musical examples given above: I do not see how it can be done.

IV

\section{RIGHTS AND REMEDIES}

The preceding discussion of music theory showed that in comparing musical works there are no bright lines. There is, instead, a spectrum of similarity and difference. The question of whether works are "too similar" cannot be avoided in copyright hitigation. However, rather than try to formulate how this line could be drawn doctrinally, I will argue that careful application of remedial provisions can draw this line, as it were, automatically.

The question of when a work is "too similar" can largely be answered by tearing down the conceptual wall separating facts proving liability from facts proving damages. This approach, to be developed in greater detail below, ${ }^{106}$ shifts the inquiry from the vague, general right to be free of "infringement" 107 to more specific rights. For example, the copyright holder enjoys the right to be free from injury to his market caused by copying of protectible material. ${ }^{108}$ If the extent of market injury is assumed to be related to the degree of similarity-acoustic, semantic, and aesthetic-between the plaintiff's work and the defendant's, then proof of probable or already-mcurred market damage can substitute for a specific and abstract inquiry into the more difficult issue. ${ }^{109}$

The apportionment of profits doctrine, which if properly apphed would protect only the composer's interest in her creative labor, can be employed similarly. Were courts to adopt a rule limited to apportioning creative contributions to the work (as opposed to marketing contributions), the legal issue of substantial similarity would disappear entirely when apportionment of profits is sought. The plaintiff would be entitled

105. Krofft has been criticized for providing insufficient guidance to authors regarding the extent of permissible appropriation. Barry, supra note 77, at 26-29.

106. See infra text accompanying notes 111-63.

107. "The author's copyright is an absolute right to prevent others from copying his original [work]. ... Once it appears that another has in fact used the copyright as the source of his production, he has invaced the author's rights." Fred Fisher, Inc. v. Dillingham, 298 F. 145, 148 (S.D.N.Y. 1924).

108. See stupra text accompanying notes $85-89$, and infra, text accompanying notes 111-17.

109. The standard in Porter goes directly to the issue of probable future market harm, see supra text accompanying notes $78-85$, but it would still be useful to refine the inquiry by asking the jury whether they, as representatives of the public, would be less likely to buy the plaintiff's work if they already owned a copy of the defendant's. This would provide a check on finding market harm in every case of close similarity. 
to a recovery whenever she could show, first, that the defendant made use of her material-a question of historic fact-and second, that what was used is protectible material. The apportionment process would result in comparatively heavy damages against a defendant whose creative contributions added hittle to the value of the work, thus discouraging uncreative borrowing. Conversely, a defendant who exercises substantial creativity in his use of the borrowed material would be exposed to proportionately lower hability.

This result is not, $m$ fact, overly broad, smce many "trivial" borrowings will involve material too specific or too general to be protectible in the first place. In addition, as a practical matter, it will seldom be possible to overcome the defendant's argument of independent creation in most cases where the borrowing is insignificant. Even where copying could be shown in such marginal cases, the negligible potential recovery should work as a disincentive to litigation. ${ }^{110}$ Similarly, where the defendant makes substantial changes in the material he uses, a full consideration of the effect of these changes will create the same barriers to recovery.

\section{A. The Right to Compensation: Damages for Market Harm}

One of the more obvious rights incident to property ownership is the right to be protected against theft. But intellectual property cannot itself be stolen. The concept of theft implies not just gain to the thief, but harm to the victim. Taking someone else's musical material does not leave a hole in the original work; ${ }^{111}$ the material is duplicated, not taken. However, copying is similar to stealing in some cases, because each time the infringing work is sold, the copyright holder may lose a sale of the original. Loss of potential sales is clearly a wrong against which the copyright holder must be protected if his copyright monopoly is to have any meaning. Therefore damages must be available for harm to the composer's market caused by unauthorized copying. It is also clear that the market can be injured by something less than coinplete and literal

110. Of course, where the defendant's work is enormously profitable, a small percentage could translate into a large monetary recovery. In such cases, recourse could be had to the existing de minimis fair use rule, which says that some takings of protectible material are too small to justify recovery. See Harper \& Row, Publishers v. Nation Enters., 471 U.S. 539, 564-65 (1985). And, since I also argue that the standard for granting injunctions should not be met simply by showing copyright infringement alone, there is little risk of overbroad protection caused by the bargaining power plaintiffs gain from injunctions. See infra, Part V.

111. "[An idea's] peculiar character . . . is that no one possesses the less, because every other possess the whole of it." Letter from Thomas Jefferson to Isaac McPherson (Aug. 13, 1813), reprinted in The LIFE AND Selected WRITINGS of Thomas JefFerson 630 (A. Koch \& W. Peden eds. 1944). 
copying. ${ }^{112}$

Elaborate discussion of recovery for market damage is unnecessary here. First, this remedy is conceptually simple and widely used in a variety of legal contexts. Second, plaintiffs im music plagiarism cases generally pursue profits inore seriously than actual dainages. Where infringing musical coinpositions are involved (as opposed to infringing sound recordings), it is apparently quite difficult to prove damages to the copyright holder's market, presumably because so many variables affect profits that a drop in sales could not be reliably attributed to the defendant's use of borrowed material alone. ${ }^{113}$

One case can serve as a sufficient example of damages analysis. In Cream Records, Inc. v. Joseph Schlitz Brewing Co. ${ }^{114}$ the plaintiff sued over the defendant's use of a small portion of the plaintiff's song "The Theme froin Shaft" im the defendant's beer commercials. After tlie jury found infringement, the court determined damages. The issue on appeal was the amount due in actual damages for loss of the hicense fee. ${ }^{115}$ The trial court had reasoned that because the fair market value of a hicense to use the entire song in a commercial was $\$ 80,000$ per year, and because only a small portion of the song was actually used in the Schlitz coinmercial, "the reasonable value of a hicense for use of that portion was $15 \%$ of the value of the license to use the entire song." 116 The Court of Appeals disagreed. The proper concern, it said, was not the value of the defendant's use, but the value of the market lost to the plaintiff. The defendant's use of the plaintiff's song, however minimal, nevertheless destroyed the value of the work as a whole for any other advertising purpose. ${ }^{117}$ Because the seginent of the song taken was still recognizable, the result was to impair the market value of the song as a whole.

The situation im Cream Records suggests how market damage can provide one standard of copyright hability. If the defendant took too large a seginent of the plaintiff's work, or too catchy a part, and did not change it sufficiently to avoid interference with the plaintiff's market,

112. See Nichols v. Universal Pictures Corp., 45 F.2d 119, 121 (2d Cir. 1930), cert. denied, 282 U.S. 902 (1931).

113. See, e.g., Arnstein v. Porter, 154 F.2d 464, 467 (2d Cir. 1964) (plaintiff sought only profits); Fred Fisher, Inc. v. Dillingham, 298 F. 145, 152 (S.D.N.Y. 1924) ("As for damages, it seems to me absurd to suggest that [plaintiff] has suffered any injury.... I do not believe that the accompaniment to the chorus of [defendant's song] would have subtracted one copy or one record from [plaintiff's] sales."); MCA, Inc. v. Wilson, 425 F. Supp. 443 (S.D.N.Y. 1976), aff'd in part and modified in part, 677 F.2d 180 (2d Cir. 1981) ("[T] here is no evidence of actual or potential economic damage caused to [plaintiff] by reason of defendant's performance and sale of recordings of [the infringing song]." 677 F.2d at 191 (Mansfield, J., dissenting)).

114. 754 F.2d 826 (9th Cir. 1985).

115. Id. at $827-28$.

116. Id. at 827 .

117. Id. at $827-28$. 
then the defendant should be held hable. The defendant's use must not be such that his work will be perceived as a market substitute for the plaintiff's. Of course, one work may function as a market substitute for another without there being any copying in the first place, simply because the new work is better or more desirable for a particular use. Thus, before market damage becomes relevant, it will still be necessary for the plaintiff to show that the defendant copied protectible material froin him.

Under this proposed test, the degree of permissible sinilarity could vary depending on the use to which the defendant's version is put. For example, advertisers have been known to create jingles closely resembling popular songs in heu of licensing the popular song itself. ${ }^{118}$ Such practices often destroy the value of the popular song for potential advertisers, even if a new song with the same degree of resemblance, composed solely for the entertainment market, would not inflict a comparable injury.

However, market damages can not be the only measure of liability. In Cream Records, the cause and effect relationship between the defendant's use and the plaintiff's injury was relatively easy to show. Another company had negotiated with the plaintiff for a license to "The Theme from Shaft" and withdrew after the defendant's advertisement was broadcast. ${ }^{119}$ But, in the majority of plagiarisin cases, when the market at stake is the unpredictable market of everyday music consumers, this cause and effect will be less clear. Even a sudden drop in a plaintiff's sales immediately after the release of a defendant's song might prove nothing except the greater appeal of the latter. On the other hand, even the most straightforward imitation inay have no noticeable effect on the market for the original, since audiences are often interested in hearing what different musicians will do with the same material. Indeed, any musician is already entitled to a compulsory license for recording and marketing her own version of a nondramatic musical work previously distributed on phonorecords. ${ }^{120}$ Although this is intended only as a performance-related right, musicians nevertheless are allowed a fair degree of creative flexibility in adapting the work to the needs of their performance. ${ }^{121}$ The outer boundaries of permissible adaptation under this

118. See Goldstein, Pop Eye: B.F. Goodrich's Ad 'Tires Out' Tom Petty, L.A. Times, March 8, 1987, Calendar 80 (home edition) (temporary restraining order issued against tire company's soundalike version of plaintiff's song). Similarly, the Chrysler Corp.'s "Born in America" jingle was created after the firm was denied a license to use Bruce Springsteen's hit, "Born in the U.S.A." Id.

119. Cream Records, 754 F.2d at 827; see also Harper \& Row, Publishers, v. Nation Enters., 471 U.S. 539, 567-68 (1985) (loss of license from third party relevant factor in deciding validity of fair use defense).

120. 17 U.S.C. $\$ 115$ (1982).

121. See 17 U.S.C. $\S 115(\mathrm{a})(2)$, which provides:

A compulsory license includes the privilege of making a musical arrangement of the work to the extent necessary to conform it to the style or manner of interpretation of the performance involved, but the arrangement shall not change the basic melody or 
compulsory license may well correspond, in practice, to the point where the two works would be too different to compete directly in the entertainment market. Hence, although market damage can serve as an indicia of excessive copying in some clear cases, copyright owners would not be fully protected by a rule which rehed solely on market demographics to demonstrate illicit copying.

\section{B. The Right to Compensation: Apportionment of Profits}

Several cases have indicated that copyright holders should be compensated for their creative labor, as well as protected from injury to the market for their product. ${ }^{122}$ Because these cases do not elaborate the point, it seems worthwhile to show here why this additional protection may be deserved.

Locke's familiar theory of property acquisition holds that whenever someone, by his labor, changes a thing from its natural state, he has "mixed" his labor with it, and thereby makes it his property. ${ }^{123}$ This is so "at least where there is enough and as good left in common for others." 124 Although Locke was thinking of land, not music, there is room for a principled comparison. A composer can be said to acquire property in music by transforming, through his labor, the sounds which exist in nature.

The same argument, however, which gives one composer (call him Salieri) a property interest in his music, arguably gives a second composer (call him Mozart) a property interest in a work combining original material with material borrowed from the first. Mozart could argue that, having mixed his labor with Salieri's and having created a new work while leaving the original unharmed, that is, leaving "enough and as good" for Salieri, he, Mozart, should have the property interest in the new work. Mozart's rights in the new work-as-a-whole might be thought to trump the rights of anyone else in any part of it.

However, to mix one's labor with another person's labor is not to make the latter's labor one's own, but rather to combine the two. The property interests of both composers could be recoginized by treating Mozart's work as the product of a constructive joint authorship of Mozart and Sahieri. The law could recognize Mozart's rights in what is

fundamental character of the work, and shall not be subject to protection as a derivative work under this title, except with the express consent of the copyright owner.

122. See, e.g., Mazer v. Stein, 347 U.S. 201, 219 (1954) ("Sacrificial days devoted to . . creative activities deserve awards commensurate with the services rendered."); Orgel v. Clark Boardman Co., 301 F.2d 119, 120 (2d Cir.) (concerned with "[a]ppropriation of the fruits of another's labor and skill"), cert. denied, 371 U.S. 817 (1962); see also International News Serv. v. Associated Press, 248 U.S. 215, 242 (1918) (Inisappropriation).

123. J. LOCKE, 2 Two TREATISES OF GoverNMENT \ 27 (1690).

124. Id. 
original to him-his own original material as well as his original use of Salieri's material. The law could simultaneously recognize Salieri's rights in his own material qua material. To protect Salieri's rights in his material, Mozart must be required to compensate Salieri for its use; that is, for the benefits of his labor. This is the best conceptual basis for the right to share in the profits which the defendant's work has accrued. But if it is one's labor as a composer which is to be protected, clearly the apportionment of profits should be tailored to that labor, and not to some other sort of labor. As will be seen, the law tends instead to focus not on creative labor but on entrepreneurial labor. This occurs because courts generally consider noncreative as well as creative contributions to a work's profitability.

After discussing the history of the remedy of profits and the doctrine of apportionment, I will examine low these liave been applied in music copyright cases. Then, having charted the existing terrain, I will suggest how these doctrines could be refined.

\section{Apportionment of Profits-History and Application}

The remedial aspects of American copyriglit law have evolved gradually, ${ }^{125}$ often in a step-by-step fashion apparently tailored to the desirable results in specific cases. The apportionment doctrine is no exception. The original rule was that when profits were awarded, all of the defendant's profits went to the plaimtiff, even where the infringing work included original, noninfringing material. The court in Callaghan $v$. Myers wrote:

If the parts which have been copied cannot be separated from those which are original, without destroying the use and value of the original matter, he who has made an improper use of that which did not belong to him must suffer the consequences of so doing. If a man mixes what belongs to him with what belongs to me, and the mixture be forbidden by law, he must again separate them, and he must bear all the mischief and loss which the separation may occasion. If an individual chooses in any work to mix my hiterary matter with his own, he must be restrained from publishing the literary matter which belongs to me; ... and if by that means the injunction, which restrained the publication of my literary

125. See generally W. Strauss, Study No. 22, The Damage Provisions of the Copyright Law, in Copyright Law Revision, Studies Prepared for the Subcommittee on Patents, TRADEMARKS, AND COPYRIGHTS OF THE COMMITTEE ON THE Judiciary, UNITED STATES Senate, 86Th CoNg., 2D Sess. (Comm. Print 1961) [heremafter General Revision of The COPYRIGHT LAw]. See also the original State copyright laws collected in U.S. COPYRIGHT OFFICE, Copyright Enactments: LAwS Passed in the UNITEd States Since 1783 Relating to COPYRIGHT 1-21 (1963). Before the enactment of the first federal copyright law in 1790, five states (Connecticut, Georgia, New York, North Carolina, and South Carolina) provided for compulsory licensing where authors furnished the public with too few copies of their works, or set an unreasonable price given the author's labor, time, expense and business risk. Id. at 2-3, 13, 16, 18, 20. 
matter, prevents also the publication of his own hiterary matter, he has only himself to blame. ${ }^{126}$

Underlying this rule was the notion that a copyright holder enjoys an unqualified right to prevent unauthorized use of her copyrighted material. In defining the plaintiff's right so broadly, the court in Callaghan ignored the possibility of any redeeming value in the defendant's new creation. Conventional tort theory required complete restitution on the theory that no one should benefit from her own wrong. ${ }^{127}$ But if, as this Comment suggests, hability should be triggered only by a violation of a more specific right-that is, if the "wrong" is not the borrowing itself, but rather the consequences flowing from the borrowing-then the Callaghan rule is too harsh. Instead, a inore limited remedy should be tailored to the specific right infringed.

The Second Circuit, when presented with facts calling for this more limited response, responded by relaxing the harsh dictate of Callaghan. This was the familiar case of Sheldon v. Metro-Goldwyn Pictures Corp. ${ }^{128}$ A prior proceeding determined that defendant Metro-Goldwyn had used, without permission, certain elements of the plaintiff's play in producing its movie Letty Lynton. ${ }^{129}$ Much of the screenplay was based on uncopyrightable historical events, and on a book concening those events in which Metro-Goldwyn had acquired rights, but enough had been taken from the plaintiff's play to constitute an "infringement."130 After an appeal on the issue of hability, the case returned to the district court for a determination of damages. The district court, following the rule of Callaghan, awarded the plaintiff all of Metro-Goldwyn's profits from the movie. ${ }^{131}$ The Second Circuit, in an opmion by Judge Learned Hand, reversed and made a new award of damages based on the record below. Now, only twenty-percent of Metro-Goldwyn's profits were awarded to the plaimtiff. ${ }^{132}$

Despite the difficulty of separating the plaintiff's work from the defendant's in the final product, Judge Hand beheved "it is nearly as unfair to cast the infringer for all the profits, as it would be to deny the .. . author any recovery whatever, because he could not separate his contribution." 133 The defendant's experts claimed, and Judge Hand

126. Callaghan v. Myers, 128 U.S. 617, 666 (1888), quoting Lord Eldon in Mawman v. Tegg, 2 Russell 385, 391 (1826).

127. D. DobBs, HandBooK on the LAW of Remedies 1 (1973).

128. 106 F.2d 45 (2d Cir. 1939) (Sheldon II), aff'd, 309 U.S. 390 (1940).

129. Sheldon v. Metro-Goldwyn Pictures Corp. (Sheldon I), 81 F.2d 49 (2d Cir.), cert. denied, 298 U.S. 669 (1936).

130. Id. at 56.

131. Sheldon II, 106 F.2d at 48.

132. Id. at 51 .

133. Id. at 49-50, overruling Dam v. Kirk La Shelle Co., 175 F. 902 (2d Cir. 1910), which had refused defendant the chance to prove grounds for apportionment. 
agreed, that the main sources of the movie's profits were (1) its popular actors (Joan Crawford and Robert Montgomery), (2) its scenery, and (3) its expert producers and directors. ${ }^{134}$ Metro-Goldwyn's expert witnesses insisted that the profit-generating role of the elements taken from the plaintiff was minimal, perhaps nil. ${ }^{135}$ All of the experts' estimates were based on the contribution of the entire screenplay to the movie's profits, rather than on the contribution of the plaintiff's material to the screenplay itself. ${ }^{136}$ Although Judge Hand thought this overinclusiveness should count toward reducing the percentage of profits recoverable, ${ }^{137}$ the figure of twenty percent was intended to resolve all doubts in favor of awarding the plaintiff too much rather than too little. ${ }^{138}$

On appeal, the Supreme Court affirmed, stating:

The purpose is thus to provide just compensation for the wrong, not to impose a penalty by giving to the copyright proprietor profits which are not attributable to the infringement.

... That relief [profits] had [before being codified in the 1909 Act] been given in accordance with the principles governing equity jurisdiction, not to inflict pumishment but to prevent an unjust enrichment by allowing injured complainants to claim "that which, ex aequo et bono, is theirs, and nothing beyond this." [citation omitted] ${ }^{139}$

Although the Sheldon court moved away from Callaghan, it nevertheless still failed to ground its holding on any clearly stated basic right. Neither the Second Circuit nor the Supreme Court indicated that the apportionment should focus on the parties' actual contributions to the movie itself. Judge Hand did not speak in terms of apportioning profits based on the relative annount of creative labor each party put into the movie - that is, in terms of the quality and quantity of what each contributed. Rather, the focus was on whatever generated the movie's profits. The plot and screenplay may be a large part of the creative effort behind a movie, but here, at least, they were not a large source of the profits. Although the defendant was at least not allowed to offset the box-office effect of its "standing and reputation in the industry," 140 it could and did claim the box-office drawimg power of its movie stars. ${ }^{141}$ Such a

134. Sheldon II, 106 F.2d at 50-51.

135. Id.

136. Id. at 50.

137. Id.

138. Id. at 51.

139. Sheldon II, 309 U.S. at 399.

140. Id. at 407 (quoting lower court opinion, 106 F.2d at 50).

141. Id. at 406-07. Benjamin Kaplan has expressed unease with the apportionment rule of Sheldon II. He fears that softening the reinedy may encourage infringement and (more importantly) encourage judges to find infringement in close cases by assuring that the defendant will not be left too badly damaged. B. KAPLAN, supra note 3 , at 71. 
contribution to profits is more the product of skillful marketing than creative labor.

In a subsequent case, a district court, purportedly following Sheldon, refused to apportion profits where the defendant's contributions had no apparent value independent of their conjunction with the plaintiff's protected product. ${ }^{142}$ The case arose from the sale of infringing instruction manuals accompanied by original phonorecords. The decision was based on the assumption that "the records had no purpose when separated from the instruction manual and ... only the course as a whole had any substantial value."143 The court reasoned that profits could not be apportioned since no profits could have been derived from the sale of the records without the manuals. ${ }^{144}$ This reasoning is problematic, for the defendant's original material will seldom if ever have value apart from its function in the new work-as-a-whole. For example, on facts like those in Sheldon, such incorrect reasoning would have required the court to ask how many people would buy tickets to the movie if the infringing screenplay were somehow deleted (perhaps by turning off the soundtrack?). The focus, of course, must be instead on the value of each element to the work as a whole, not on the value of each element standing alone.

Awarding profits is said to be particularly appropriate in copyright cases, where even substantial dainages are often difficult to prove, as well as difficult to predict because of the importance of subsidiary rights in the composer's ultimate return. ${ }^{145}$ For exainple, if the defendant uses the plaintiff's work to create a derivative work, the plaintiff may lose the opportunity to create her own, possibly superior, derivative work. The defendant's profits are the best way to measure this damage. ${ }^{146}$ The apportionment rule is codified in Section 504(b) of the 1976 Act, ${ }^{147}$

142. Neal v. Thomas Organ Co., 241 F. Supp. 1020 (S.D. Cal. 1965).

143. Id. at 1022.

144. Id.

145. Letter of Irwim Karp, 3/29/57, in GENERAL REVISION OF THE COPYRiGHT LAw, supra note 125, Study No. 22 at 43-44. Evidence that Congress was aware of this difficulty is found in the renewal right given by the 1909 Act, former 17 U.S.C. $\$ \S 24-25$, and the provision for termination of transfers and licenses by the author in the 1976 Act, 17 U.S.C. $\$ 203$, both of which implicitly recognize that the value initially placed on a work may prove to be mcorrect with the passage of time.

146. Letter of Irwin Karp, supra note 145.

147. 17 U.S.C. $\$ 504(b)$ (1982). The remedial aspects of the 1909 Act were examined during the General Revision which led to the 1976 Act, GENERAL REvision of THE COPYRIGHT LAW, supra note 125 , Studies 22,23 and 24 , but met with hittle criticism. In the words of one commentator whose views were solicited by the Copyright Office:

[A]lthough the damage provisions of the statute are far from perfect, they have worked quite well and need little if any revision. As construed by the courts, these provisions do not seem to have worked any great hardship upon copyright proprietors or users of material, except perhaps in isolated cases.

Id. Study No. 23, letter of John Schulman, 4/1/58, at 97.

Participants in the revision process argued that any copyright remedy package must "make an 
which provides:

The copyright owner is entitled to recover ... any profits of the infringer that are attributable to the infringement and are not taken into account in computing the actual damages. In estabhishing the infringer's profits, the copyright owner is required to present proof only of the infringer's gross revenue, and the infringer is required to prove his or her deductible expenses and the elements of profit attributable to factors other than the copyrighted work.

The last clause of Section 504(b) appears to allow the court to consider the defendant's noncreative contributions to profit. In addition, it treats apportionment essentially as an affirmative defense which can be used to reduce the defendant's recovery after liability is established (through an "illicit copying" test). Hence, under the Act, the plaintiff need only prove "enough" copying to establish infringeinent, in order to shift the burden to the defendant to show what was not copied and what role other factors played in generating profits. In contrast, if liability were triggered by appropriation of creative labor, the apportionment of that labor would be the very essence of the plaintiff's case. It would be up to the plaintiff to identify the copied elements of the defendant's work. The factfinder would use this evidence, as well as the defendant's evidence showing what inaterial, if any, had been independently created, to apportion the creative effort that produced the defendant's work as a whole. Before elaborating this idea, it will be helpful to see how the existing rule is applied in cases involving musical works. ${ }^{148}$

author whole for the damages he has suffered, deter infringement, and make it impossible for others to obtain involuntary licenses." Id. Study No. 22, letter of Irwin Karp, 3/29/57, at 43; see also id., letter of Edward A. Sargoy, 5/6/57, at 47: "[T]he existence of such sanctions underlies the consciousness of everyone who is tempted to appropriate something to which he may not be entitled, without making a deal for what he wants."

148. Often, m music infringement cases, apportionment merely mvolves the profits generated by one song on an album or concert of several. See, e.g., Frank Music Corp. v. Metro-Goldwyn-Mayer, Inc., 772 F.2d 505, 514-19 (9th Cir. 1985) (Las Vegas revue); ABKCO Music, Inc. v. Harrisongs Music, Ltd., 508 F. Supp. 798 (S.D.N.Y. 198I) (records), modified, 722 F.2d 988 (2d Cir. 1983); Lottie Joplin Thomas Trust v. Crown Publishers, 456 F. Supp. 531 (S.D.N.Y. 1977) (records), aff'd, 592 F.2d 651 (2d Cir. 1978). In these situations the court must estimate how much of the market appeal of the entire record or concert is due to the infringing song. In the Lottie Joplin case, two songs out of a five-record set of the complete works of Scott Joplin were recorded without perinission. The plaintiff claimed that the set only had value as a complete works collection, that the two unlicensed songs were necessary for that purpose, and that the plaintiff was, for that reason, entitled to the entire amount earned by the set. The court rejected this argument, as well as the defendant's argument that the plaintiff should only recover a straight per-cut percentage, and instead awarded one-half of the set's profits. $456 \mathrm{~F}$. Supp. at 538.

In $A B K C O$ Music, where the infringing song appeared on records alongside original songs, Judge Owen noted that although "exactly the same mechanical royalty is payable ... for each [song] on any given record, whether memorable or not, ... a hit song contributes more to the sale of a record than does a less popnlar song." 508 F. Supp. at 800 . The Court emphasized the evidential value of BMI moritoring of air play, and came up with three separate apportionments, one for the single (taking into account the less-popular flip side), one for a double-album containing 
In $A B K C O$ Music, Inc. v. Harrisongs Music, ${ }^{149}$ Judge Owen considered the damages George Harrison should pay for his subconscious infringement of the Chiffon's song "He's So Fine," which suppled much of the music for Harrison's "My Sweet Lord."150 The Chiffon's song had lain dormant for about fifteen years after spending a few months at the top of the charts. Harrison's song used a virtually identical tune, similar harmony, but different lyrics. ABKCO Music, the holder of the "He's So Fine" copyright, ${ }^{151}$ sought a share of Harrison's profits, but apparently did not seek actual damages. What portion of the profits of "My Sweet Lord" could be attributed to factors other than the plagiarized music? Admitting that precise measurenent was impossible, Judge Owen determined that the original lyrics of "My Sweet Lord" and the "selling power of [Harrison's] name" contributed $25 \%$ of the song's profits, the remainder coming from the "plagiarized tune."152

At least one other post-Sheldon case distinguished between profits earned by infringing music and profits earned by original, noninfringing lyrics, ${ }^{153}$ but apparently no court has yet atteinpted to analyze the profitgenerating impact of each inusical element of a work. For example, "My Sweet Lord" differs froin "He's So Fine" in instruinental arrangement

comparatively less popular songs, and finally, one for an album of "hit" songs (a straight per-cut apportionment). Id. at 801 .

149. 508 F. Supp. 798 (S.D.N.Y. 1981).

150. Liability was established in Bright Tunes Music Corp. v. Harrisongs Music, Ltd., 420 F. Supp. 177 (S.D.N.Y. 1976).

151. Bright Tunes had been replaced as plaintiff by ABKCO Music, Inc. by the time of the damages hitigation. ABKCO Music, Inc. v. Harrisongs Music, Ltd., 722 F.2d 988, 990-92 (2d Cir. 1983). The hitigation was complicated by alleged professional misconduct on the part of Allen $B$. Klein-the ABK of ABKCO-who had been Harrison's attorney during the initial phases of the copyright infringement suit. After being fired by Harrison, he apparently interfered with the settlement Bright Tunes and Harrison were negotiating by purchasing the copyright in "He's So Fine" and substituting himself as plaintiff. As a result of this misconduct, a constructive trust was imposed on the fruits of ABKCO's purchase, to be turned over to Harrison after payment of Klem's purchase price. $508 \mathrm{~F}$. Supp. at 803 . Judge Owen nevertheless described the apportionment of profits which would have been appropriate absent Klein's misconduct.

152. 508 F. Supp. at 801-02. Judge Owen indicated that, had Harrison deliberately plagiarized "He's So Fine," the court would have awarded the plaintiff all of the earnings of "My Sweet Lord". Id. at $801 \mathrm{n.10}$. This is bad law: no other case has treated the defendant's motivations as a factor in apportioning profits. Under Sheldon, the purpose of awarding profits is to provide "just conipensation," not to impose a penalty. See supra text acconipanying notes 128-39.

153. MCA v. Wilson, 425 F. Supp. 443 (S.D.N.Y. 1976), aff'd in part and modified in part, 677 F.2d 180 (2d Cir. 1981).

Where there has been intentional cooperation between composers and their literary or choreographic collaborators, Italian law gives the composer the mdependent right to exploit the work economically, but requires profit-sharing: "In operas, the value of the inusical part shall be regarded as being three-quarters of the total value of the work[, and in] operettas, [songs and dance pieces], the value of the two contributions shall be cousidered equal." Legge n. 633 of 22 aprile 1941, art. 34, Gazzetta Ufficiale 622, 631, translated in UNESCO, COPYRIGHT LAwS \& TREATIES of THE WORLD (1984). Art. 35 severely restricts the rights of the nonmusician collaborator to sever his contribution from the inusic. 
and, in places, harmony, yet these two elements did not enter into the court's calculations. ${ }^{154}$

\section{A Second Look at Apportionment}

Two problems stand out im the current approach to apportionment. First, the present apportionment system focuses on the wrong concernthat is, on profit-generation rather than creative labor. Second, courts fail to delve deeply enough into the works at issue in performing their apportionment. These two problems will be discussed in turn.

Current doctrine apportions profits according to the earnings thought to be generated by each party's contributions, of whatever sort, to the market popularity of the infrimging work. ${ }^{155}$ As a practical matter, this emphasis is likely to minimize recovery in any case where the defendant is more famous than the plamtiff. This is illustrated by the Sheldon court's emphasis on the drawing power of the movie star's names, and the Harrisongs court's consideration of the selling power of George Harrison's name. ${ }^{156}$ Under such a rule, a defendant can benefit from copying even where his only "improvement" was to add his saleable name to the package.

A better approach is to examine only the contents and audience appeal of the fimshed work itself, ignoring the commercial effect of extramusical elements. The factfinder would still consider the effect of each party's contributions on the value of the work, but only musically creative contributions would be relevant. For example, in an appropriate case a defendant could argue that a handful of small changes turned the plaintiff's inconsequential song imto something marvelous, and therefore the song's financial return was due entirely to the defendant's creative labor. A good tune has value, a bad tune none, and the differences between the two may be slight. ${ }^{157}$ If the defendant managed to turn

154. Judge Owen at least gave a cursory glance to musical differences, concluding that original introductory musical material in Harrison's song "was a minimal [ie., irrelevant] factor." $A B K C O$ Music, 508 F. Supp. at 802 n.11.

155. See supra text accompanying notes $128-41$.

156. Judge Owen should not have considered the drawing power of Harrison's own name, just as Metro-Goldwyn could not rely on its name in the Sheldon case. See supra text accompanying note 140. Even Sheldon did not go far enough, though, since that decision allowed Metro-Goldwyn to plead the box office effect of its stars' names, as distinct from their actual performance contribution to the movie. Similarly, the skill Harrison and his band brought to their recording of the work was certainly an element of the song's success which could properly have been considered under the current rule. Judge Owen's procedure gives an unfair benefit to successful performers, especially those who plagiarize the work of less-successful colleagues. Indeed, even the mere presence of a "star" in the courtroom may have a powerful prejudicial effect on juries. See UPI, 12/15/84 (Michael Jackson's appearance for the defendant in Sanford v. CBS.)

157. Becthoven's sketchbooks demonstrate this principal. He revised his material constantly, often over several years. Versions of the same section would often differ only by a few notes or rhythmic values. See V. ZuCKerkand, MAN THE Musician 312-31 (N. Guterman trans. 1973). 
dross into gold with his creative contributions, he should reap the rewards. To give the plaintiff a substantial recovery under these circumstances would allow her a reward incommensurate with her contribution to society. ${ }^{158}$ Conversely, soine plaintiffs could inake the parallel argument that although what was taken from them was small in comparison to the defendant's work as a whole, the borrowed elements made the difference between a successful work and a failure. Perhaps the Letty Lynton screenplay was made more successful because the heroine used strychnine rather than arsenic to poison her lover, or because the victim was a Latin American rather than a Swede-perhaps not. True qualitative improvenients, if such they are, are the essence of creative labor, and should be rewarded.

An apportionment which includes extramusical elements of profitgeneration misconstrues the rationale for awarding the reniedy in the first place. Copyright law should protect creative labor, not entrepreneurial ability. The borrower does not through his infringement turn the original composer into an unwilling joint venturer, but into an unwilling joint author. It is quite sensible to remedy this situation by recognizing in law what is true in fact, that the work created by the borrower is the work of both parties. But the apportionment, to effect this reinedy, must apportion the work, not the commercial venture.

This brings us to the second problem, the failure of courts to delve deeply enough into the works at issue in calculating apportionnent. Minute dissection is necessary to an apportionment of creative labor. ${ }^{159}$ Such an apportionment could occur at any of three levels. The first and nost obvious approach is to distinguish the specific work at issue from other wholly-original works sold alongside, as in a record album or concert. The second is to separate the strands of the work itself-screenplay from sets, music from lyrics. The third approach, one which the law has yet to try, is to separate the fibers within the strands: chord from chord, word from word. All the various aspects of the music should be examined; its "beat", its instrumental arrangement, its specific choice of chords, would all be proper factors for consideration. Furthermore, as

158. This suggests that there is an economic value to the recognition of quality. This view is implied in H. LAdDie, P. Prescott \& M. Vitoria, The Modern LAW of Copyright 18 (1980) (originality seen as the "exercise of substantial independent skill, judgment or creative labour . . . Rossini used machines to generate some of his themes, but he still had to select the wheat from the chaff.") Much of the art of composing consists of troubleshooting, figuring out exactly why material is not sounding right; once the problem is identified, the solution is usually a relatively simple matter. Taste is a large share of talent: a tune that is good enough for a Salieri may be fiawed to the ear of a Mozart. The defendant's argument here assumes-with good reason-that society benefits from the improvements he makes.

159. A thorough exploration of the siguificance of detail to the process of composition is found in V. ZUCKERKANDL, supra note 157, at 219-353. 
the earlier discussion of the comparison of musical works ${ }^{160}$ suggests, the factfinder should also consider the effect of the new context on the borrowed material as an element of the defendant's own creative labor.

As a practical matter, a judge or jury may well have trouble distinguishing fame from merit. ${ }^{161}$ Unfortunately, little can be done to eliminate this risk, beyond careful attention to the actual comparisons of the works themselves, and perhaps a cautionary instruction. Although it is true that factfinders generally lack the resources and expertise to perform the ideally subtle musical analysis needed for a perfect apportioninent, the exclusive focus on creative contributions would at least produce a better, fairer apportionment, tied to the purposes of protection. Judge Hand's award of twenty percent for a screenplay, and Judge Owen's award of seventy-five percent for a tune, could hardly have been more than random guesses on their parts; more appropriate and more probing evidence could at least make such guesses educated ones.

It might also be argued that this theory violates the rule against basing protection on artistic merit. ${ }^{162}$ However, the necessary requirement of copyrightability regardless of merit is not affected. Merit merely helps define the recovery in the context of dividing up profits, where it cannot be denied that merit plays a role. Indeed, the current doctrine already allows evidence of merit - as measured by audience appeal-to affect the apportionment. Any apportionment that does more than count notes, any apportionment that assigns greater value to the tune than to the chords, ${ }^{163}$ necessarily makes a value judgment.

\section{$\mathrm{V}$}

\section{The Right To Prohibit USE}

The existing law gives a composer tlie distinct right to prevent any unauthorized use of her copyrighted material, even if compensation is offered. This right is enforceable by means of injunctive relief. ${ }^{164}$ This section challenges the rationale for this remedy, and argues that its use

160. See supra Part II.

161. In the course of a chamber music concert on February 4, 1837, featuring Liszt, an innocent hoax was perpetrated on the unsuspecting Paris public. In order to make a better effect the programine was turned around, the Beethoven trio changing places with a trio by [Johann Peter] Pixis. No announceinent was made. The audience applauded vigorously after the Pixis trio, thinking it to be by Beethoven; the Beethoven trio drew a lukewarm response, everybody assuming it to be by Pixis.

A. WALKER, 1 Franz LiSzT 227 (1983).

162. See supra note 87 and acconpanying text.

163. See supra note 154 and accoinpanying text.

164. 17 U.S.C. $\S 502$ (1982). Injunctions are frequently requested in plagiarism cases. Recent examples include requests for injunctions agaiust a parody of Madonna's "Papa Don't Preach" (AP, 11/13/86), against Paul Overstreet's "Diggin' Up Bones" (UPI, 1/16/87), against the theme from "Chariots of Fire" (AP, 2/11/87), and against Michael Jackson's and Walt Disney Co.'s film "Captain Eo" (UPI, 6/24/87). 
should generally be limited to situations where it is the only possible way to prevent uncompensable harm to the plaintiff's market. Where the only right infringed is the right to compensation for one's creative labor, a compulsory hicense would be the more appropriate remedy.

The conventional purpose of injunctive rehef is to avoid future harm. ${ }^{165}$ Courts have generally considered any future infringing use of copyrighted material as sufficient "harm" to justify this extreme form of relief. ${ }^{166}$ Consequently, a defendant can avoid a permanent imjunction only if he can distinguish and remove that portion of his work taken from the plaintiff. Early doctrine also denied the permanent injunction where the imfringing material was a particularly small part of the defendant's work, ${ }^{167}$ but this factor seems no longer to be considered. ${ }^{168}$ Under modern practice, any use entitling the plaintiff to monetary rehief imposes on the defendant the additional burden of choosing between severance of the infringing material or prohibition of the entire work. In the case of musical compositions, severance will generally be impossible.

The right to the injunction thus follows from the premise that any "infringing" use violates the plaintiff's right not to have her copyright mfringed. If, as I have suggested, ${ }^{169}$ this is too vague a right to be meaningful, and if, therefore, the focus should shift to more specific rights such as protection of the plaintiff's market and compensation for her labor, then mjunctions would only be appropriate to the extent necessary to protect these specific rights. ${ }^{170}$ The use of injunctions to protect against future market harm is uncontroversial. However, the use of an injunction to protect the right to compensation for one's labor is harder to sustain, since compulsory licensing would seem, on its face, to offer sufficient protection.

However, compulsory hicenses-conferring the riglit to use another's property witlout her consent but for a fee-are provided for by

165. D. DoBes, supra note 127 , at 108-09.

166. See, e.g., Sheldon v. Metro-Goldwyn Pictures Corp., 81 F.2d 49, 56 (2d Cir.) (injunction granted where only a small portion of plaintiff's play was used), cert. denied, 298 U.S. 669 (1936); Northern Music Corp. v. King Record Distributing Co., 105 F. Supp. 393, 401 (S.D.N.Y. 1952) (mjunction granted for infringement of eight bars of music); Fred Fisher, Inc. v. Dillingham, 298 F. 145, 152 (S.D.N.Y. 1924) (injunction granted where Jerome Kern used an eight-note ostinato figure from plaintiff's song). The grant of an injuuction in Sheldon is criticized in Goldstein, Derivative Rights and Derivative Works in Copyright, 30 J. COPYR. SOC. OF THE U.S.A. 209, 237-38 (1983).

167. See Dun v. Lumbermen's Credit Ass'n, 209 U.S. 20, 23 (1908) (infringement of reference book: "the proportion [of pirated material] is so insignificant coinpared with the injury from stopping appellees' use of their enonnous volume of independently acquired information, that an injunction would be unconscionable." Plaintiff was left to its remedy in damages).

168. See cases supra note 166. See also 3 NIMMER, supra note 1, at § 14.06[B].

169. See supra Part IV.

170. Because I see advantages in setting the threshold for monetary recovery fairly low (at least conceptually), it is necessary to consider a standard for granting injunctions which is not linked directly and automatically to the award of money damages. 
statute in only a few situations, involving either specific technologies ${ }^{171}$ or users who cannot know that they are infringing because of a lack of copyright notice. ${ }^{172}$ Outside of these situations, courts invariably assune that nonconsensual uses inust either be both permissible and free, or coinpletely prohibited. ${ }^{173}$ The alternative, of course, is to permit nonconsensual uses but require payment for thein. ${ }^{174}$ This approach is hardly new; it is solnetimes taken in other areas of property law. ${ }^{175}$ Two distinct questions arise in its apphication to copyright law: can a court inpose a

171. See 17 U.S.C. §111(c) (1982) (cable television); §115 (making phonorecords); § 116(b) (jukeboxes); $\S 118$ (certain works used by noncommercial broadcasters). These licensing schemes are operated under the supervision of the Copyright Royalty Tribunal, whose decisions are subject to limited judicial review. 17 U.S.C. $\$ 810$. Congress clearly did not intend an active judicial role in rate-setting.

172. See 17 U.S.C. $\S 405(b)$ (court may, in its discretion, allow continued infringing use upon payment of a rcasonable license fee); $\S 907(a)(2)$ (innocent purchaser of infringing semiconductor chip product liable only for reasonable royalty).

173. Nonconsensual uses which are both permissible and free arise either because the substantial similarity test is not satisfied, or because of a successful fair use defense. The latter is, in effect, a privilege granted to specific users in specific circumstances to use a work in a way that would otherwise incur hability. See, e.g., Williams \& Wilkins Co. v. United States, 487 F.2d 1345 (Ct. Cl. 1973), aff'd, 420 U.S. 376 (1975).

174. This alternative is argued in Timberg, A Modernized Fair Use Code for the Electronic as Well as the Gutenberg Age, 75 Nw. U.L. Rev. 193 (1980); see also Gordon, Fair Use as Market Failure: A Structural and Economic Analysis of the Betamax Case and its Predecessors, 82 CoLUM. L. REV. 1600 (1982). But see Fernay, Grandeur, Misère et Contradictions du Droit d'Auteur, 109 REVUE INTERNATTONALE DU DROIT D'AUTEUR 139, 171 (1981) (exclusive rights only way to fully protect authors); GeNeral Revision of THE COPYRIGHT LAW, supra note 125, Study No. 22, letter of Irwin Karp, 3/29/57, at 43 (copyright law must "make it impossible for others to obtain involuntary licenses.")

Another commentator has suggested that courts should have the power to impose a license where the user has attempted, unsuccessfully, to seeure a lieense on reasonable terms. Clemmons, Author v. Parodist: Striking a Compromise, 46 OHIo ST. L.J. 3, 16-17 (1985). This approach is used by Australia, India and Ghana, and five American states adopted this procedure before enactment of the federal copyright law. See Australia, Copyright Act $\S 157(3)$, AusTL. C. ACTS (1968); India, Copyright Act § 31, 7 INDIA GEN. R. \& O. (1960); and Ghana, Copyright Act § 12, No. 85 (1961) (aggrieved potential licensee may apply to the respective nation's Copyright Tribunal to set a reasonable licensing fee). For a list of the state laws, see supra note 125 .

175. Patent law, in particular, often provides for licenses rather than injunctions. See, e.g.. Stickle v. Heublein, Inc., 716 F.2d 1550, 1563 (Fed. Cir. 1983) (distinguishing between compulsory license and implied in law license; in this case the court recognized the existence on the facts of the latter, permitting continued use of existing machines once the plaintiff receives full compensation for them); Foster v. American Machine \& Foundry Co., 492 F.2d 1317, 1324 (2d Cir.) (injunction is a matter of discretion; equities in this case favored compulsory license instead), cert. denied, 419 U.S. 833 (1974).

Nuisance law is similar. See, e.g., Northern Indiana Pub. Serv. Co. v. W.J. \& M.S. Vesey, 210 Ind. 338, 200 N.E. 620 (1936) (same); Boomer v. Atlantic Cement Co., 26 N.Y.2d 219, 228, 257 N.E.2d 870, 874-75, 309 N.Y.S.2d 312, 319 (1970) (denying injunction and awarding permanent damages imposing a servitude on the land); see also Restatement (SECOND) of TORTS $\S 951$ comment a.

The law of publicity rights is comparable as well. See Zacchini v. Scripps-Howard Broadcasting Co., 433 U.S. 562 (1977) (television station entitled to show plaintiff's circus act but must compensate plaintiff for this use). 
compulsory license absent a provision for one in the copyright statute; and should it do so in a particular situation?

The first, procedural question has yet to be decisively answered. ${ }^{176}$ In The Betamax Case, ${ }^{177}$ the Ninth Circuit found the defendants-manufacturers of video cassette recorders-liable for copyright infringement arismg from hoine taping of television programs, and instructed the district court on remand to consider granting a continuing royalty or lump suin damages instead of an injunction. ${ }^{178}$ However, the Supreme Court reversed on the issue of hability, ${ }^{179}$ leaving this remedial possibility open to debate. ${ }^{180}$

The strongest argument agaimst judicial licensmg authority is that Congress has already specified the remedies available in copyright actions, providing for compulsory licenses only in specific instances, and only where enough data on the affected industries has been collected so that rates can be set appropriately. ${ }^{181}$ This suggests that compulsory licenses in copyright law may be a matter solely for legislative, not judicial, action. ${ }^{182}$ However, the statutory compulsory licenses involve large, novel industries with hundreds of thousands of users. In these situations, a judicially created license based only on the facts of a particular case miglit fail to balance adequately the competing interests at stake. In addition, such a hicensing scheme would not usually apply to anyone except the parties to the case. Consequently, license fees set by courts inight not be as uniform as those determined by a statute of general application.

In contrast, the situations addressed in this Comment involve lighly specific parties and works; here, only individualized, ad hoc decisions are possible. Courts are more competent than Congress to balance such particularized interests $\mathrm{m}$ deciding whether to grant a license, and to set appropriate terms. ${ }^{183}$

176. 17 U.S.C. $\$ 502$ (a) gives the court power to "grant ... injunctions on such terms as it inay deem reasonable to prevent or restrain infringement of a copyright." Although this clearly inplies the power to deny injunctive relief, it does not necessarily imply the power to grant compulsory licenses.

177. Universal City Studios v. Sony Corp. of America, 659 F.2d 963 (9th Cir. 1981), rev'd, 464 U.S. 417 (1984).

178. Id. at 976 .

179. Sony Corp. of America v. Universal City Studios, Inc., 464 U.S. 417 (1984).

180. Justice Blackmun's dissenting opinion approved the idea of a licensing scheme. Id. at 499 . 500 (Blackmun, J., dissenting).

181. See, e.g., 94th Cong., 2d Sess. 1976, P.L. 94-553, 359-68.

182. See Gordon, supra note 174, at 1622-24; Timberg, supra note 174, at 241; Note, The Betainax Case: Accommodating Public Access and Economic Incentive in Copyright Law, 31 STAN. L. REV. 243, 260-61 (1979).

183. Indeed, Congress designates the courts, rather than itself or the Copyright Royalty Tribunal, to set royalties in the innocent-infringer cases, where inore individualized determinations are necessary. 17 U.S.C. $\S 405$ (b) (1982). 
Another argument in favor of the judicial power to grant licenses derives from the clear power of courts to deny injunctions in appropriate circumstances. ${ }^{184}$ Although Professor Nimmer asserts that the current state of the law virtually requires an injunction where continuing infringenent is threatened, he nevertheless advocates denying injunctions which would cause great public imjury. ${ }^{185}$ The Nimth Circuit approved this arguinent in The Betamax Case. ${ }^{186}$ The court, however, clearly indicated that prospective harm to the defendant was not a relevant concern in deciding whether to grant or deny an injunction. ${ }^{187}$ This differs from the standard in other areas of property law, where both the public interest and the interests of the particular defendant are considered. ${ }^{188}$ The true scope of a court's discretion therefore remains in doubt.

The second, substantive, question is whether courts should grant compulsory hicenses rather than injunctions in music plagiarism cases, assuming that the former is within their power. A compulsory license might be inappropriate if copyright infringement were considered an act of theft. ${ }^{189}$ If an infringer harms the copyright loolder by the very act of taking protected inaterial (instead of merely incurring a liability to him), an injunction would be appropriate for the same reasons that tlieves are punished instead of charged for the value of what they steal. First, plagiarists-like thieves-are not caught every time. The costs assessed

184. See D. DoBBS, supra note 127, at 108; B. KAPLAN, AN UNHURRIED VIEW OF COPYRIGHT 73 (1967): "Courts have sometimes forgotten that an injunction does not go of course; the interest in dissemination of a work may justify a confinement of the remedy to a money recovery ...;" see also W. Strauss, Study No. 24, Remedies Other than Damages for Copyright Infringement, in GENERAL REVISION OF THE COPYRIGHT LAW, supra note 125, pointing out that injunctions are both discretionary and extraordinary, and require balancing the effects of the injunction on the two parties. But see letter of R. Walker, 5/4/59, id. at 133, commenting on this Study and noting that injunctions have high value as instruments of deterrence, often more so than money remedies.

185. 3 Nimmer, supra note 1 , at $\S 14.06$; see also Nimmer, Copyright Liability for Audio Home Recording: Dispelling the Betanax Myth, 68 VA. L. REV. 1505, 1529-34 (1982) (discussing schemes for coinpulsory licenses).

186. 659 F.2d at 976.

187. Id. Compare Austria, Urheberrechtsgesetz [UrhG] § 82(4) (infringing articles not to be destroyed if another remedy would involve less or no destruction of value of plaintiff's work).

The British Secretary of State for Trade has recominended taking into account the gravity of the infringement and the damage to the plaintiff if the injunction were granted. CoPYRIGHT AND

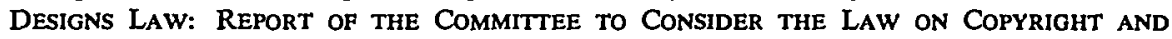
DESIGNS 180 (March 1977). However, the English law remains as harsh as the American. See E.P. SKONE JAMES, J.F. MUMmeRY \& J.E. RAYNER JAMES, COPINGER AND SKone JAMES ON COPYRIGHT 264-66 (12th ed. 1980).

Additionally, where only a preliminary injunction is sought, courts will balance equities, considering whether the works are presently in competition, and whether granting a preliminary injunction would damage the defendant far more than refusing it would harm the plaintiff. See Life Music, Inc. v. Wonderland Music Co., 241 F. Supp. 653, 656-57 (S.D.N.Y. 1965) (preliminary injunction sought against song "Supercalifragilisticexpialidocious" from the movie Mary Poppins).

188. See Nimmer, Copyright Liability for Audio Home Recording, supra note 185, at 1530 n.88.

189. The following discussion springs largely from Calabresi \& Melamed, Property Rules, Liability Rules, and Inalienability: One View of the Cathedral, 85 HARV. L. REv. 1089 (1972). 
to the apprehended plagiarist must be sufficient to act as a deterrent, taking into account the low probability of "capture", and should help defray the costs incurred by the copyright holder in policing its rights. Second, even if all plagiarists were called to account, one could argue that there is an independent societal interest in maintaining the exclusivity of property and in protecting an author's ability to naine her own price-or to refuse to sell at all. ${ }^{190}$ In any case, a license fee could only approximate the true value of the author's property.

Several arguments, however, weigh in favor of compulsory licenses and against the broad use of injunctions. First, the borderlines of the plaintiff's property are not well staked out; the law already permits some use of the plaintiff's work, and it nnay be difficult for a composer to know whether his use falls on the safe side of the line. Not only is the legal boundary vague, but also the creative one: a composer can never be coinpletely sure that the inusical inaterials which seein to occur to him spontaneously are not supplied by his memory rather than the Muse.

Second, even if a composer knows that he is using copyrighted material beyond permissible limits, the use of that material may occur in a rush of "inspiration", and thus becone woven into the fabric of his originat work-in-progress. Creative use may occur before there is any reasonable opportunity to negotiate a license, ${ }^{191}$ and the composer may be loatl to unravel his work if the copyright holder's price is too high.

Third, the societal interest in new artworks, even if it does not excuse borrownig, ${ }^{192}$ at least weighs against depriving the public of the results. ${ }^{193}$ Finally, in cases where the plaintiff's inarket is not adversely affected, the copyright holder, unlike the robbery victim, loses little by the plagiarism. In such cases, an injunction desigued to prevent future harm will usually be unjustified.

Where the plaintiff is likely to experience actual harm from continued use, especially future harm to the work's market, an mjunction is obviously inore important. Such liarm may be noneconomic. It has been

190. Id. at 1125-26.

191. This concern has been weighed in other copyright contexts. For example, the fair use standards negotiated for classroon photocopying include "spontaneity" as a factor, requiring that

[t]he inspiration and decision to use the work and the inoment of its use for maximum teaching effectiveness are so close in time that it would be unreasonable to expect a timely reply to a request for permission.

H.R. REP. 1476, 94th Cong. 2d Sess. 69 (1976) (Agreement on Guidelines for Classroom Copying in Not-for-Profit Educational Institutions).

192. But see Beardsley, Notes on Forgery, in THE Forger's ART 225, 231 (D. Dutton ed. 1983), arguing that because of the public interest in having great artworks, any means are appropriate which produce such works.

193. Soine cominentators have advocated a copyright system which determines the scope of protection by balancing incentives to create original works against incentives to create subsequent works so as to provide society with the maximum amount of original expression. See Barry, supra note 77, at 29-36; Goldstein, supra note 166 , at 236 . 
argued that composers should be protected against uses of their works which are offensive to them. ${ }^{194} \mathrm{~A}$ judicially imposed license, based on market value, will fail to compensate for moral liurt. In the plaintiff's view, her creativity is thus undervalued. Any remedial system which takes moral mjury imto account would have to balance this legitimate moral claim against the danger that otherwise justifiable compulsory licenses may be denied whenever the plamtiff alleges a subjective, and therefore virtually irrebuttable, moral outrage.

Where no real injury to the plaintiff is likely, economic or otherwise, the mjunction will offer little legitimate benefit to the plaintiff, but will impose a great burden on the defendant. The plaintiff in sucl a case most often seeks an injunction to serve as leverage and improve his bargaining position, rather than to attain just compensation. Professor Dobbs writes:

[T] his is not the purpose of the injunction, and it gives the plaintiff a monetary imcome in excess of the damages he proved in court [as a result of the settlement freeing the defendant from the injunction]. It penalizes the defendant in a way not provided for by the statute or intended by the judge. It is simple extortion made possible by a judicial decree. ${ }^{195}$

An additional concern is that art works themselves inight be entitled to, or already possess, a special class of rights. ${ }^{196}$ The most obvious example is the sometimes advocated riglit of a painting not to be destroyed or defaced. ${ }^{197}$ Such a right would protect the art object against all people, includimg its owner and its creator. Injury to an art work includes any diminisliment or distortion of the work's aesthetic effect. ${ }^{198}$ An example in musical terms would be a performance of Mahler's Second Symphony by a particularly mept junior higli school orchestra and chorus. If destruction is one sort of injury from which an artwork should

194. See, e.g., MCA v. Wilson, 425 F. Supp. 443 (S.D.N.Y. 1977) (use of song closely resembling plaintiff's in pornographic musical), aff'd in part and modified in part, 677 F.2d 180 (2d Cir. 1981). But see Shostakovich v. Twentieth Century-Fox Film Corp., 196 Misc. 67, 80 N.Y.S.2d 575 (1948) (no protection against offensive use of uncopyrighted works), aff'd, 275 App. Div. 692, 87 N.Y.S.2d 430 (1949).

195. D. DoBBS, supra note 127 , at 445.

196. This theory originated in Tormey, Aesthetic Rights, 32 J. OF AESTHETICs \& ART CrITICISM [hereinafter JAAC] 163 (1973). For subsequent commentary and debate see Goldblatt, Do Works of Art Have Rights?, 35 JAAC 69 (1976); Hein, Aesthetic Rights: Vindication and Vilification, 37 JAAC 169 (1978); and Sparshott, Why Artworks Have No Right to Have Rights, 42 JAAC 5 (1983).

197. Sparshott, supra note 196, at 6 (comparing rights of artworks with rights of slaves under Roman law); compare Article 6bis of the Berne Convention for the Protection of Literary and Artistic Works (Paris Revision 1971); and the California Art Preservation Act, CAL. CIvIL Code $\S 987$ (West 1982), which protect artworks from mutilation or destruction. Both the Berne Convention and the California Act view this protection primarily as part of the author's moral rights. However, the California' statute specifically recognizes "a public interest in preserving the integrity of cultural and artistic creations," distinct from the author's interests.

198. Tormey, supra note 196, at 167. Tormey calls this "aesthetic pain." 
be protected, perhaps plagiarism is another. However, it is doubtful that plagiarizing a work similarly injures its aesthetic effect. The injury-tothe-artwork theory is more relevant to parody than to more straightforward borrowing of material.

On the other hand, this theory provides an additional argument for protecting the partially-infringing work against injunction. A permanent injunction against an infringing work amounts to destruction of the work itself, not merely the defendant's rights in it. ${ }^{199}$ Is such destruction justified? The strongest reason to grant a permanent injunction is to avoid damage to the plaintiff's market, but even that interest could often be protected by the less extreme remedy of delaying the entrance of the defendant's work into the market.

"One of the central ... reasons for valuing art works is also a cominon reason for valuing persons, viz., their uniqueness or individuality." 200 This value is not due to the indispensability of given artworks or people, but to their irreplaceability. ${ }^{201}$ The greater our reluctance to destroy the irreplaceable, the greater should be the interest required to justify the destruction of an artwork.

\section{CONCLUSION}

Music plagiarism hitigation has suffered from often poor legal and musical analysis. Concepts originating in cases involving movies, books, and cartoons have been apphed reflexively in cases involving musical works. The results have been Procrustean. The purpose of this Comment has been, first, to point out some crucial facts about the nature of the composition process and of music itself. These facts were applied to the question of what it means to "copy", and to the question of how musical works can be more intelligently compared. Second, this Comment has sought to explore the underlying concerns copyright law must protect, in order to determine what the legal response to creative borrowing should be.

I have argued for a legal framework based on redressing specific injuries to specific rights, rather than one which rehes on ad hoc decisions

199. Unless the defendant can break the imjunction, no further copies can be produced, limiting the audience to, at best, a second-hand market.

This concern is addressed by Norway's Copyright Law of May $12,1966, \S 56$, which provides in part: "If important economic or artistic valnes will ... be lost [due to destruction of the imfringing work], the court may ... in given circumstances rule that the produced copies be made available to the public against compensation or redress to the offended party." (translated in UNESCO, COPYRIGHT LAWS \& TREATIES OF THE WORID (1984)).

If the music has been recorded, economic efficiency would dictate weighing the investment of the recording company as well.

200. Tormey, supra note 196 , at 169.

201. Id. 
based on a generalized tort of "infringement." I have tried to formulate a framework which fits as much as possible within the existing copyright law, while also being more sensitive to the needs, predilections and expectations of composers.

Music is a highly technical yet often imprecise field. Copyright must cope with this imprecise sophistication as best it can. The law must be adaptable to changes in the theory and practice of real-life compositional activity. It must offer a degree of certainty and predictibility in regulating and protecting this activity. Above all, it must carefully protect legitimate rights while not erecting barriers to desirable, innovative uses of material out of a merely reflexive interest in protecting the abstract sanctity of a copyright. So far, the law has largely failed in carrying out this responsibility. To steal an ending from another coinposer, this failure can only result in silly law, silly music, or silly both. ${ }^{202}$

Aaron Keyt*

202. Randall, supra note 45 , at 122 .

- B.A., B.Mus. 1983, University of Washington; third-year student, Boalt Hall School of Law, University of California, Berkeley. 